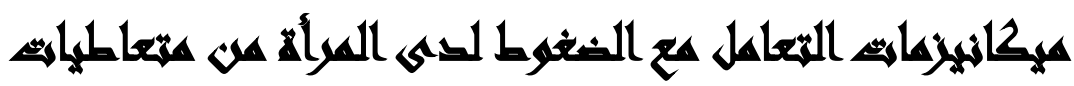 المخدرايت
}

[ᄉ]

$$
\begin{aligned}
& \text { جمال شفيق أحمد(')- أحمد عصمت شومان(")- أحمد فخري هاني(") }
\end{aligned}
$$

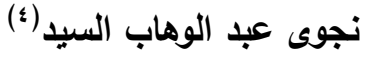

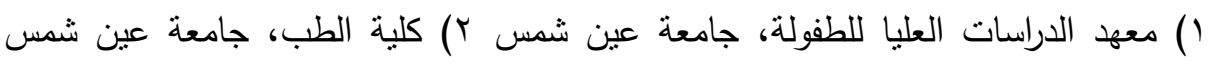

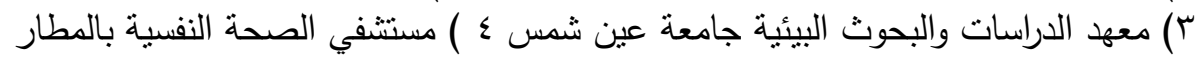

\section{المستخلتص}

تهدف الدراسة الحالية الى معرفة الضغوط البيئية والاجتماعية والاقتصادية والنفسية

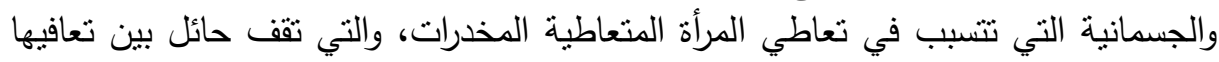

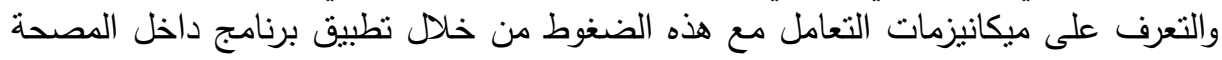

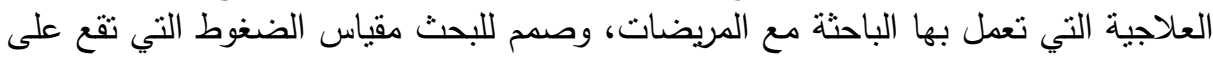

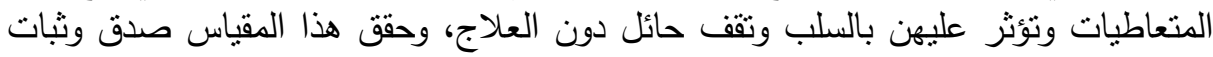

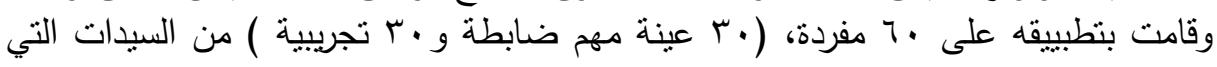

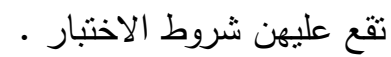

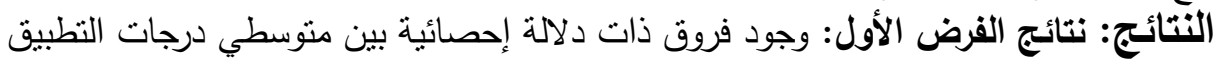

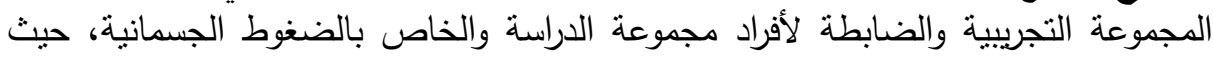

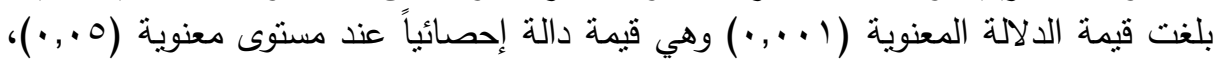

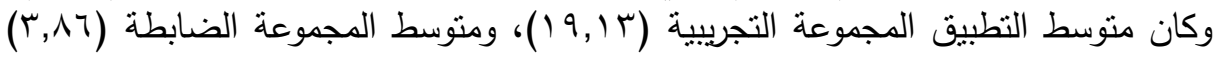
لصالح المجموعة التجريبية.

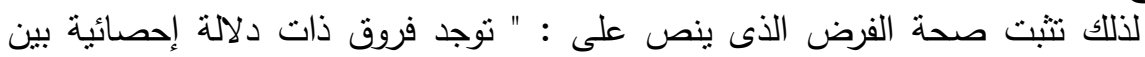
متوسط درجات أفراد الدراسة في مقياس الضغوط الجنسمانية للمجموعة الضابطة والتجريبية لصالح المجموعة التجريبية".

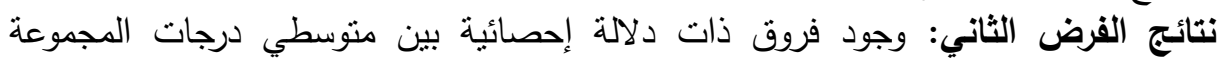

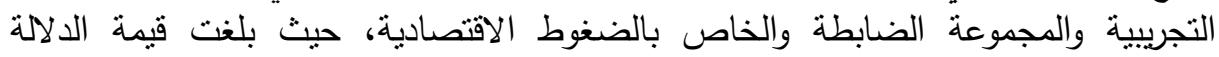

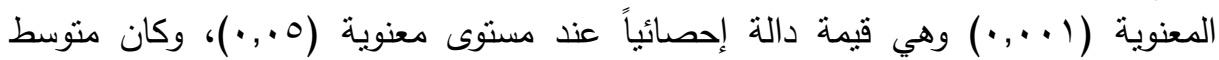

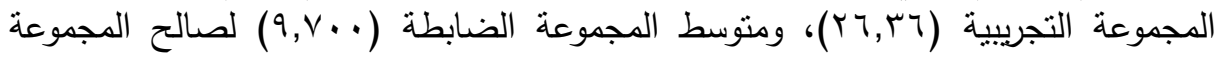


لذلك تثبت صحة الفرض الذى ينص على :" توجد فروق ذات دلالة إحصائية بين متوسط درجات أفراد الدراسة في مقياس الضغوط الاقتصادية للججموعة الضابطة والتجريبية ل الصالح المجموعة التجريبية".

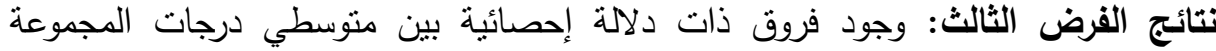

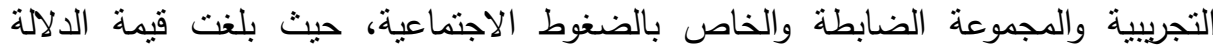

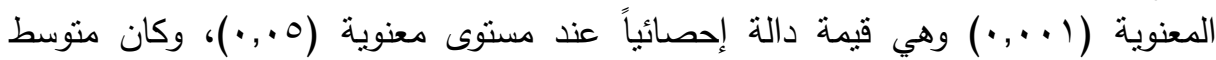

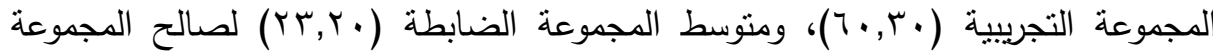

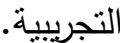

لذلك تتبت صحة الفرض الذى ينص على :" توجد فروق ذات دلالة إحصائية بين

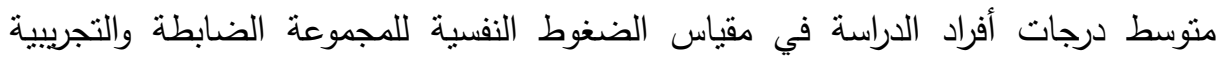
لصالح المجموعة التجريبية". نتائج الفرض الرابع: وجود فروق ذات دلالة إحصائية بين متوسطي درجات المجموعة

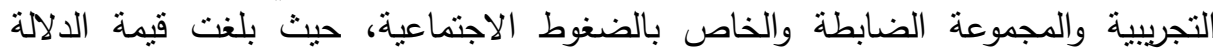

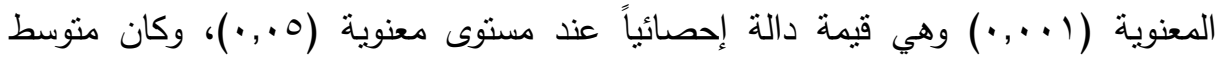

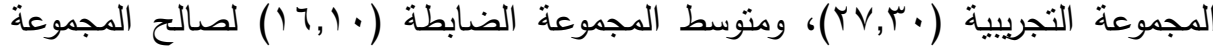

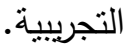

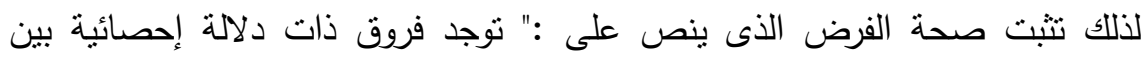
متوسط درجات أفراد الدراسة في مقياس الضغوط الاجتماعية للمجموعة الضابطة والتجريبية لـالح المجموعة التجريبية". نتائج الفرض الخامس: نوجد فروق ذات دلالة إحصائية بين متوسط درجات أفراد الدراسة في

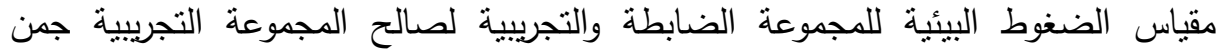

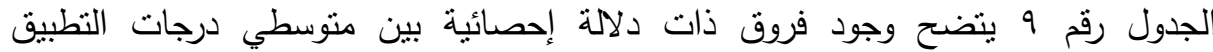
المجموعة التجريبية والضابطة لأفراد مجموعة الدراسة والخاص بالضغوط الباتية البيئية الاجتماعية،

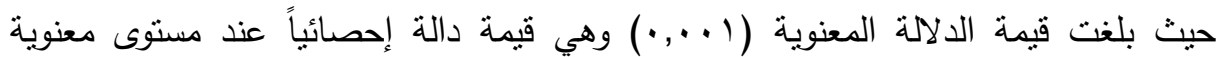

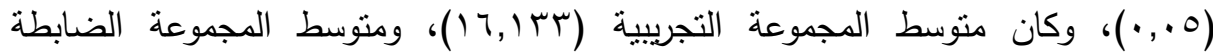
(1) (1) (10,1) لصالح المجموعة التجريبية. نتائج الفرض السادس: نوجد فروق ذات الفئ دلالة إحصائية بين متوسط درجات أفراد الدراسة في

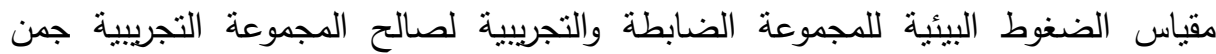

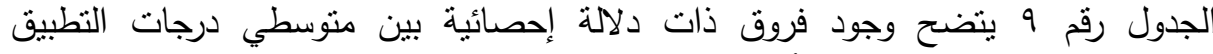

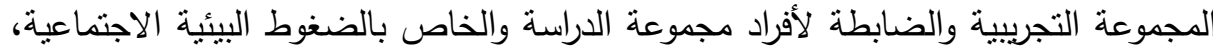

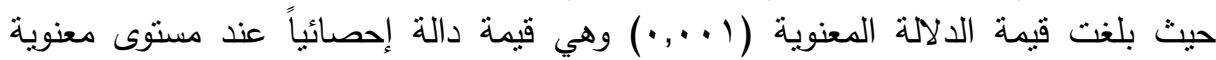




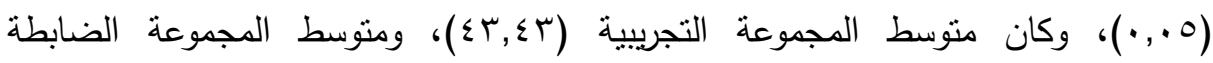

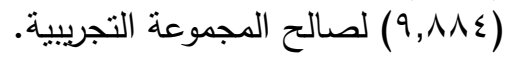

\section{منهمج التراسلة}

تتبع الدراسة الحالية المنهج الوصفي المقارن حيث يقوم هذا المنهج على أساس دراسة المتغيرات كما هي في الواقع دون أحداث أي تعديل عليها وكذلك بين المتغيرات.

\section{xaradl}

من الواضح للجميع في هذا العصر انتشار ظاهرة المخدرات على المستوى الدولي

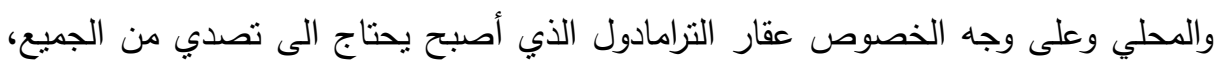

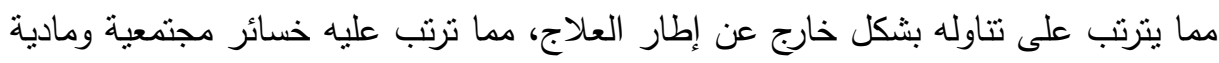

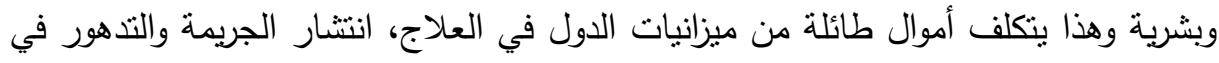
القدرات العقلية للمتعاطين والبدنية، وانتشار ظاهرة أطفال الثوارع، وقد ساهمت في انتيار انتشار الثورات والفوضى التي تجناح العالم وكثرة التكتلات وأصبح كل ذي مصلحة سياسية يسيطر

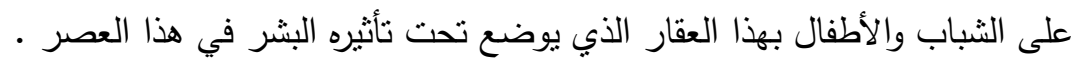
وفي ظل الظروف الاقتصادية الراهنة ذات التعاطي بسبب احتياج الأسر للإنفاق وخصوصًا للمرأة المعيلة حيث إنها تحتاج الي ما بساعدة علي الأعمال الثاقة .

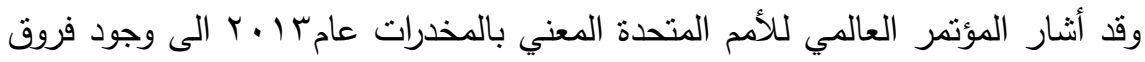
بين دول وأخرى في نعاطي المخدرات وآثرها وإنتاجها وتراوحت نسبة من يتعاطي المخدرات

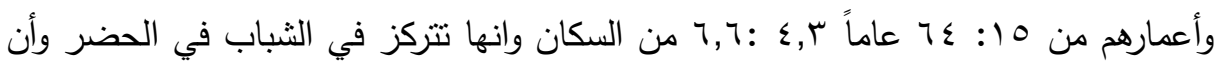
مشكلة التبغ تتركز في هب\% من عدد السكان. (المركز القومي للبحوث الاجتماعية والجنائية

\section{أهساهيم السواسما}

1- معرفة أثز الضغوط النفسية على المرأة متعاطية المخدرات r- معرفة أثز الضغوط الاقتصادية على المرأة متعاطية المخدرات r- معرفة أثر الضغوط الاجتماعية على المرأة متعاطية المخدرات

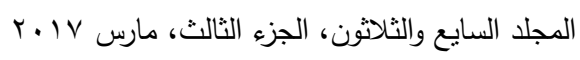


ع - معرفة أثز الضغوط البيئية على المرأة متعاطية المخدرات

0- معرفة أثز الضغوط الجسمانية على المرأة متعاطية المخدرات

\section{هزونه القراسلا}

1-توجد فروق ذات دلالة إحصائية بين منوسطات درجات العينة المريضات والصحيحات في

الضغوط النفسية - على مقياس الضغوط النفسية المصمم لذلك نوجد فروق ذات دلات دلالة

إحصائية بين منوسطات درجات العينتين في الضغوط الجسمانية - على مقياس -

الضغوط النفسية .

r-توجد فروق ذات دلالة إحصائية بين متوسطات درجات العينة الضابطة والتجريبية في

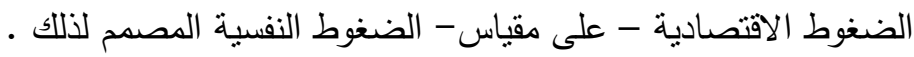

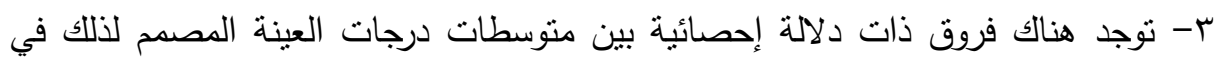

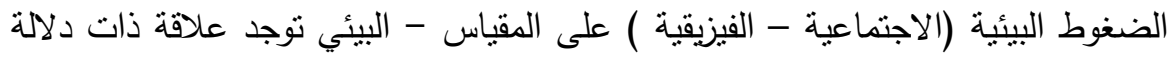

إحصائية بين منوسطات درجات الضغوط النفسية المصمم لذلك والبيئية والجسمانية

والاقتصادية والعينة التجريبية على المقياس النفسي والبيئى .

\section{أهمه التصواسم}

الأهمية النظرية: أهمية موضوع الدراسة:

1-تسعى الدراسة الحالية الى التعرف على أنواع الضغوط التي تتعرض لها الررأة في المجتمع المصري والتي تتسبب في إدمان بعضهن عقار الترامادول وعدم استطاعتها

$$
\text { التوقف عن التعاطي. }
$$

r-قد يقلل العلاج والوقاية من التعاطي من الخسائر التي تقع علي وزارة الصحة وزارة

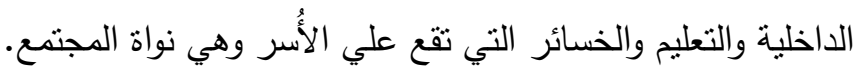


الأهمبة التطبيقية:

1- تصميم مقياس خاص بالمرأة متعاطية ترامادول التي تكثف عن الضغوط التي تقع عليها

$$
\text { وقد تسبب التعاطي (النفسية - الجسمانية - الاقتصادية) }
$$

r- تصميم مقياس بيئي يضم الضغوط (الاجتماعية والفيزيقية)

r- ورد في السنوات السابقة من إحصائيات الجهاز المركزي للمحاسبات أنه تقع خسائر فادحة على وزارة الصحة ووزارة التعليم ووزارة الداخلية أنه قد تتفق مبالغ طائلة لمواجهة

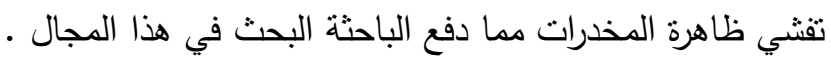
جدول(1): جدول المسح الثامل (صندوق مكافحة وعلاج الإدمان) 10 •ب (التابع لرئاسة الوزراء)

\begin{tabular}{|c|c|c|c|c|c|c|}
\hline 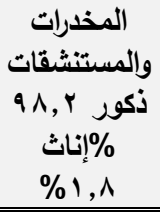 & تعاطى المخدرات & 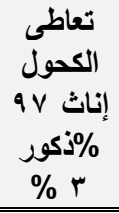 & 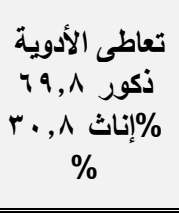 & التدخين & اللتعاطية & التعاطي \\
\hline$\% q, \vee z$ & اقل من • 1 سنوات & $\% 1 \cdot, \varepsilon$ & $\% 1 \leq$ & $\% \backslash \wedge, 7$ & $\% r r, \wedge$ & من 19 الى 19 \\
\hline$\% r v, q$ & 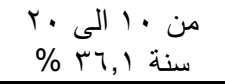 & $\% r \leqslant, 0$ & $\%$ rq,० & $\%$ rV & $\% r r, T$ & من • \\
\hline$\%(1,1$ & 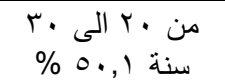 & $\% \backslash 9, r$ & $\% 19, r$ & $\% q, r$. & $\% \backslash \vee, \wedge$ & من · "r \\
\hline$\% \backslash \leq, \varepsilon$ & 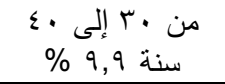 & $\% \backslash \leq, 9$ & $\% \backslash \vee, \varepsilon$ & $\% \backslash \wedge, r$ & $\% \quad 1 \leq, 7$ & 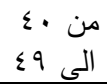 \\
\hline$\%$ IV & $\begin{array}{c}\text { من · ع فأكثر } 1,7 \\
\%\end{array}$ & $\% r \cdot, q$ & $\% 19,9$ & $\%$ rq,r & $\% r r, r$ & 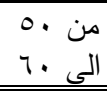 \\
\hline
\end{tabular}

\section{هجالاهت التصواسم}

تتحدد الدراسة الحالية بكل من المجال البشري، الهجال المكاني والمكان الزماني لها:

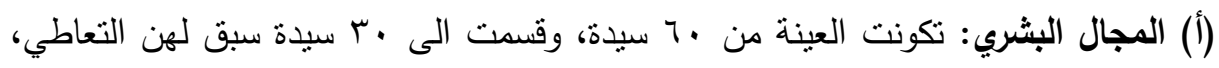

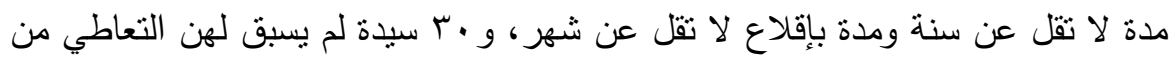

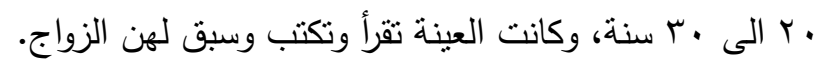


(ب) المجال المكاني: تجرى الدراسة في مسنتفى المطار للصحة النفسية ومستشفى العباسية وبعض الممرضات في مسنتفي بالمطار بالصحه النفسية.

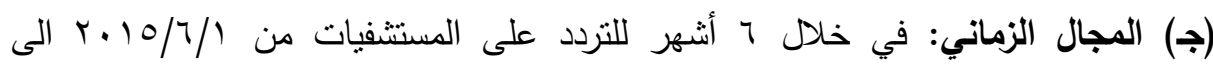
$r \cdot 10 / 1 \mathrm{r} / 1$

\section{الإسار المظليهي}

نظرية مارشال: وفي هذا النموذج يحدد مارشال العوامل المسببة للضغوط في العمل، والأعراض التي تظهر على الفرد نتيجة تعرضه لضغوط العمل، وهي أعراض خاصة بالفرد

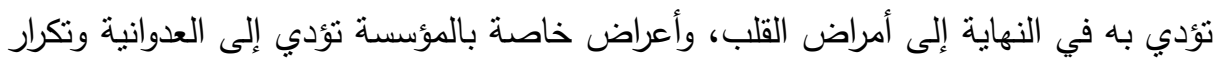
الحوادث، ويمكن رصد نموذج مارشال في الثكل (1).

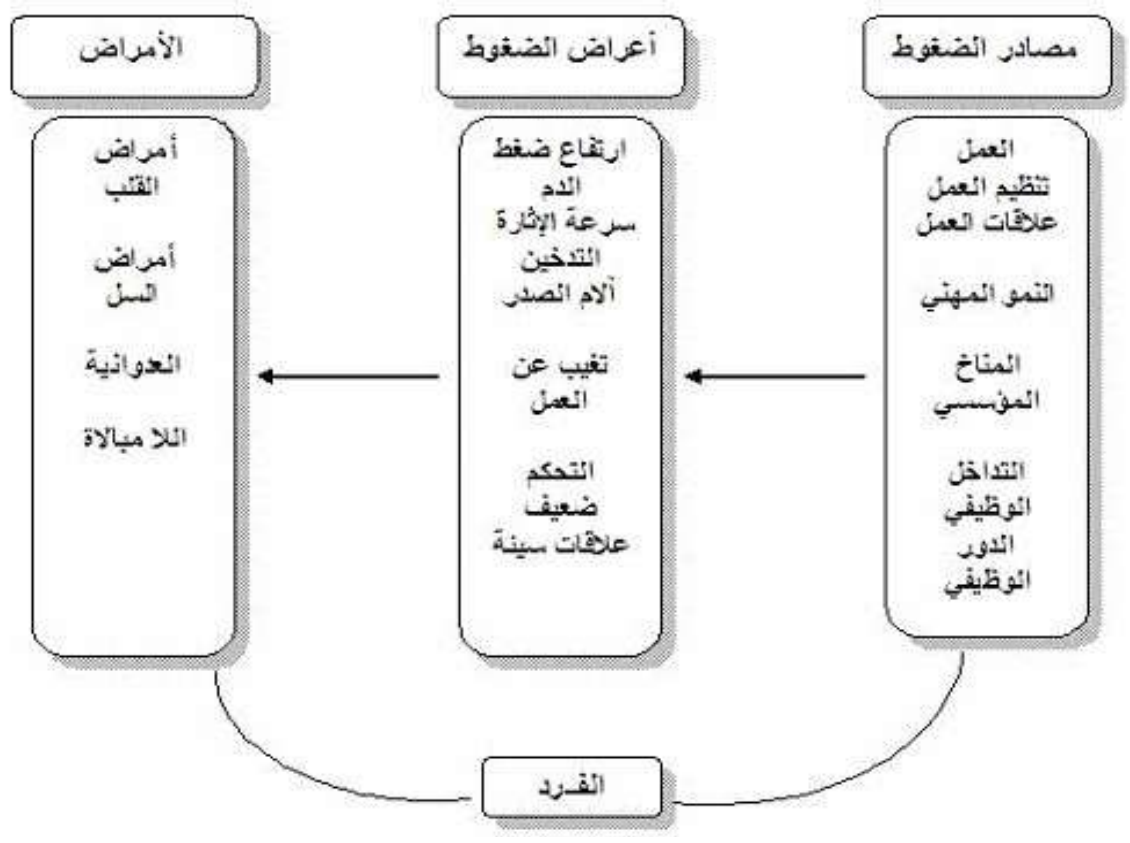

الشكل( (): يوضح نموذج مارشال للضغط (فاروق السيد عثمان، 102:2001) 
نظرية أوبر: يوضح آوبر أسباب وتأثنير الضغوط على الفرد، ويذآر "آوبر" أن بيئة الفرد تعتبر مصدراً للضغوط، مما يؤدي إلى وجود تهديد لحاجة من حاجات الف رد أو يشكل خطراً

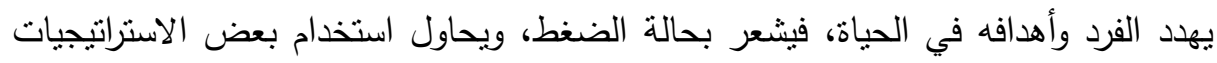

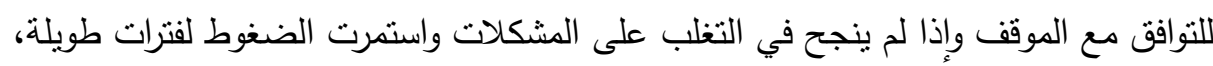
فإنها تؤدي إلى بعض الأمراض منل أمراض القلب والأمراض العقلية، آما تؤدي إلى زيادة

القلق والاكتئاب، و انخفاض نقدير الذات. ويمكن رصد نموذج "آوبر" في الثكل (r).

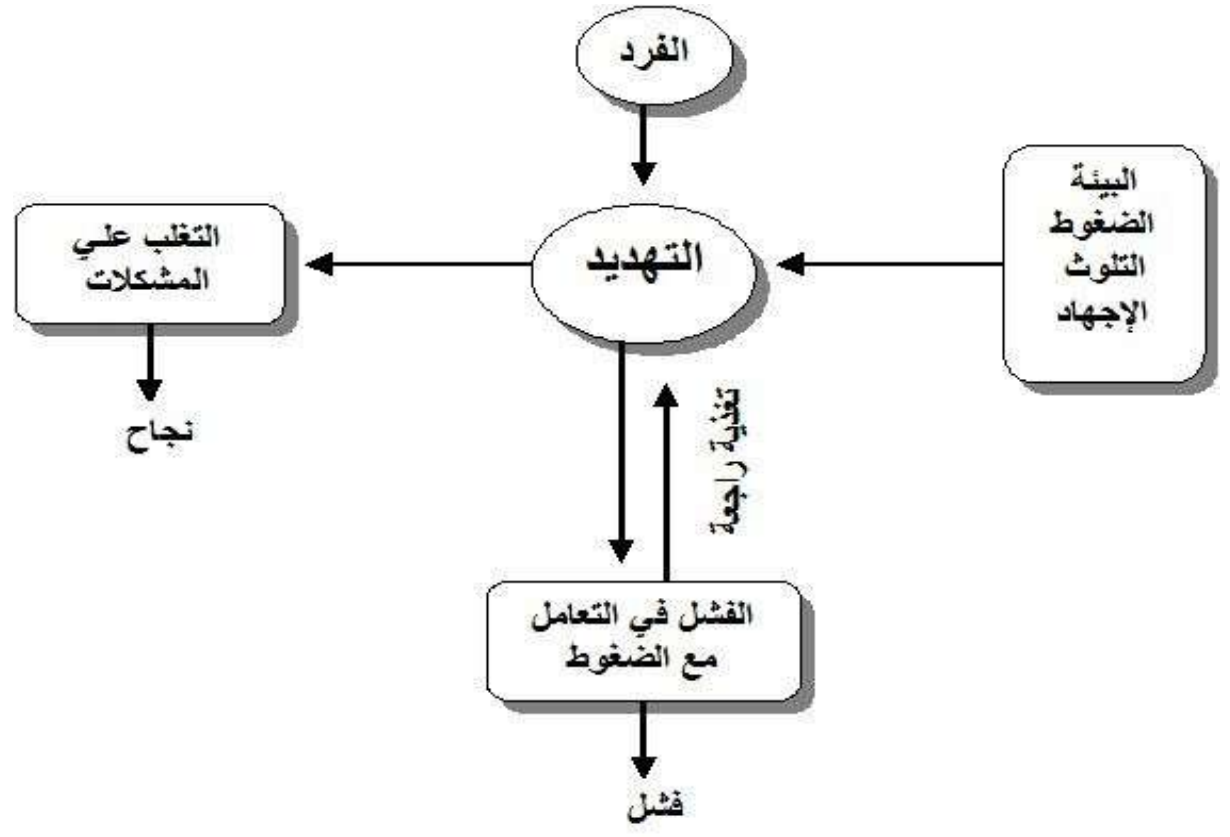

الثكل(ץ): يوضح نموذج آوبر يوضح بيئة الفرد آنموذج للضغوط (فاروق السيد عثمان، (1. r:2001

الاتجاه النظري: نظرية حفظ المصادر لهويفول 9 أو ا: برى هوبفول أن الضغط

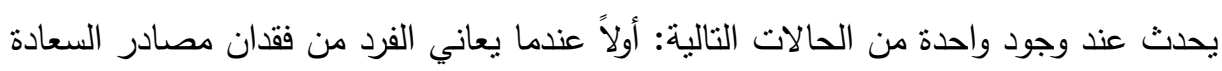

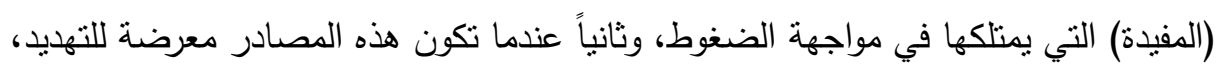

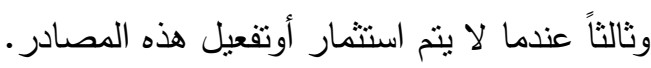


- المخدرات في اللغة: مشتقة من الخِذر .. وهوستر يُمد للجارية في ناحية البيت، والمخَدر

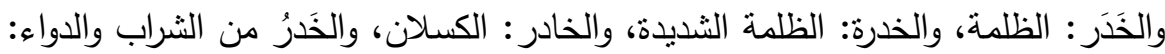

$$
\text { فتور يعتري الثارب وضعف (المعجم الوجيز) }
$$

- تعريف المخدرات:هي مادة إما تكون سائلة تؤخذ عن طريق الحقن تحت الجلد أو في

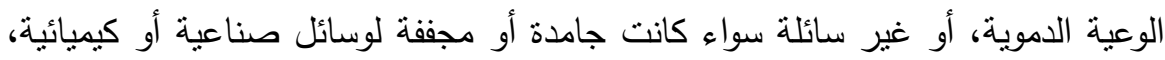

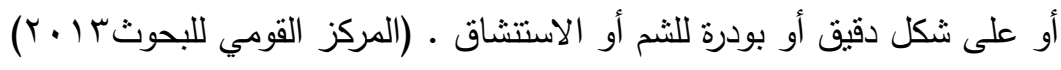

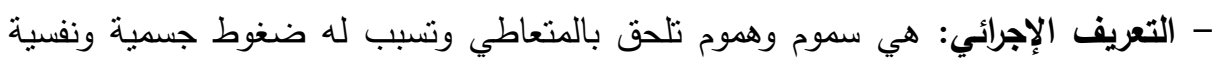
واقتصادية واجتماعية وفيزيقية يكثف عنها المقياس المصمم للكثف عن متغيرات الدراسة بهات كأو كل مادة تؤثز على العقل وتمنعه من التحكم في هوى النفس. - الترامادول: يعد عقار الترامادول مسكن أفيوني مصنف تحت فئن فئة المسكنات الأفيونية

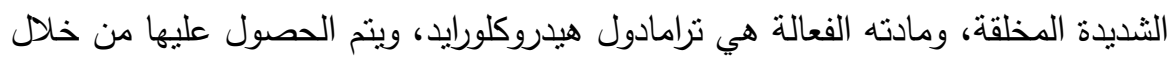
عدة مراحل كيميائية معقدة، حامض استايل ساليسيليك الاسبرين: والتي يتم تحويلها ببعض هئل

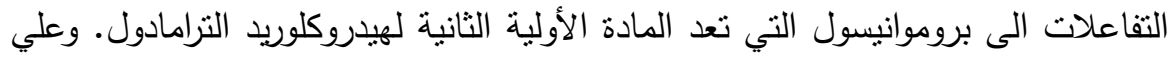

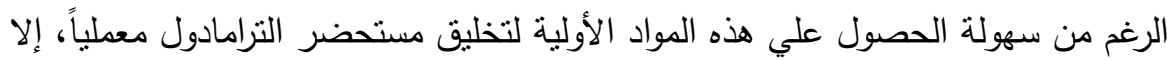
أن تفاعلاته غاية في التعقيد ولا تتم إلا في المعامل المجهزة بتقنيات حديثة ووسائل

Amphetamines الاضطرابات المتعلقة بتعاطي الامفيتامينات (المنشطات) Intoxication - مضاعفات سوء استخدام الترمادول Complications : هيئة الغذاء والدواء الأمريكي

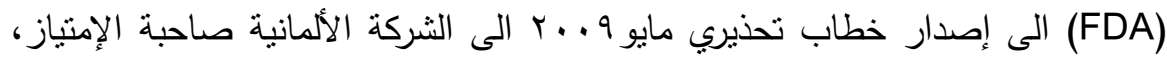
وكذلك الثركات المصنعة للعقار داخل الولايات المتحدة، وذلك بعدما روجت هذه الثركات

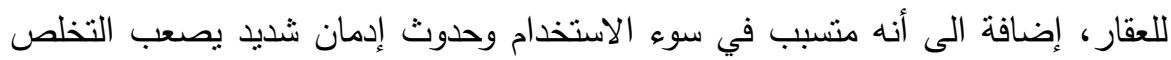
منه، والذى أكدته الدراسات التي أجرتها الشركات المنتجة، كما أشنارت الى الى استخدام

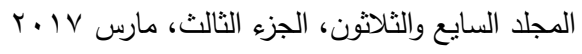


مستحضر الترمادول بدون أو مع الأدوية التي تؤثز على الجهاز العصبي قد يؤدي الى لى

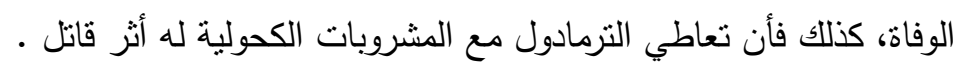

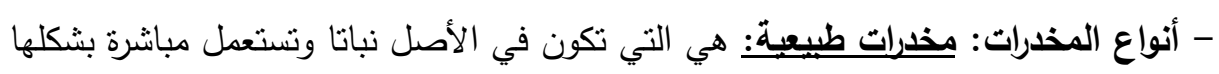
الأصلي عن طريق الفم، مثل الحشيش والأفيون والكوكا والقات .

- تعاطي المواد النفسية Drug abuse : يشيع بين كثير من الكتاب العرب أن يستخدموا في هذا الصدد تعبير "سوء استعمال المخدرات" وهذه العباره ترجمة حرفية للكلمة الانجليزية abuse

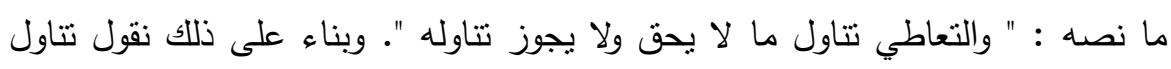

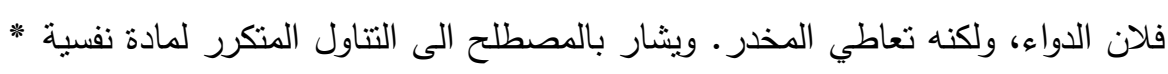

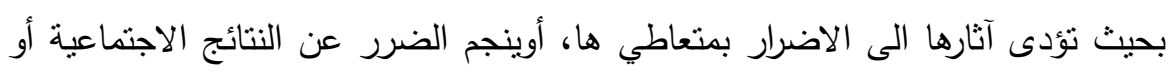
الاقتصادية المترنبة على التعاطي. (Who Dictionary 1988)

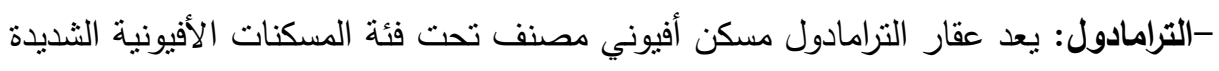
المخلقة، ومادته الفعالة هي نرامادول هيدروكلورايد، ويتم الحصول عليها من خلادل عده

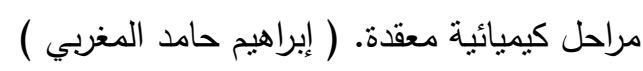

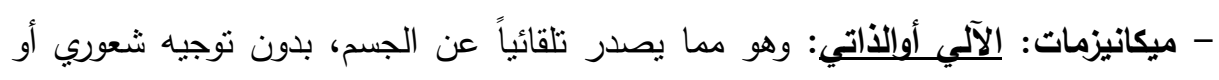

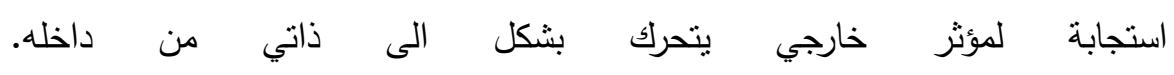
(http://www.almaany.com)

- التعريف الإجرائي للميكانيزمات: هي أساليب التعامل مع الضغوط التي يكثف عنها المقياس النفسي والبيئي الذي يكثف نقاط الضعف والقوة في شخصية المريضات ويجيب عليه الرسم البياني للمقياس.

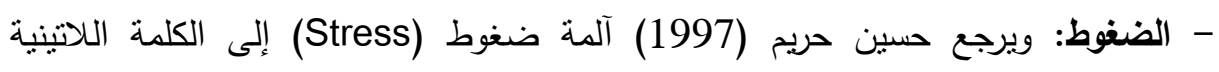

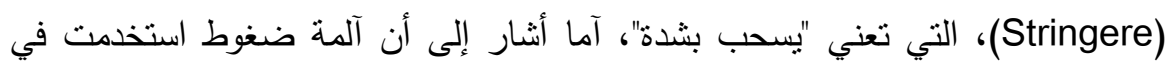

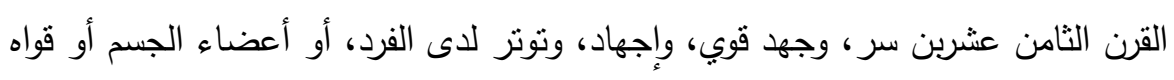

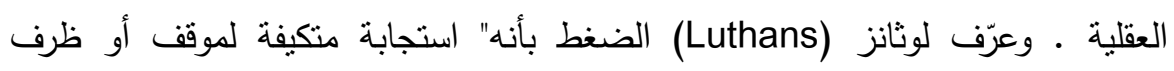


خارجي ينتج عنه انحراف جسماني، أو نفساني، أو سلوكي لأفراد المنظمة. (حسين حريم، (378:1997

ومصطلح الضغوط: يستخدم للالالة على نطاق واسع من حالات الإنسان الناشئة آثر فعل

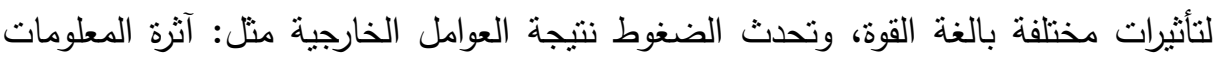
التي تؤدي إلى إجهاد انفعالي. - التعريف الإجرائي للضغوط: التي يحددها نتاتج المقياس المُّد لذلك ويدلل عليه نوع الضغوظ وشدتها لدى المرأة عبنة الدراسة.

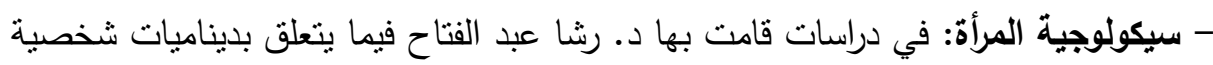
المتعاطيات للمواد ذات التاثير النفسي الحالثين مختلفتين في المستوى المادي اغتصاب الحالة الأولى في سن الخامسة وافتقاد القدوة للحالة الثانية نسبب في ادمان الحالثين(1)

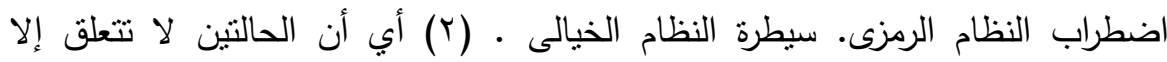
بالمخدر والنهم الفمي الذى يتوقف عند مستوى الحاجة أو شراهة الطلب لموضوع حاجاتها

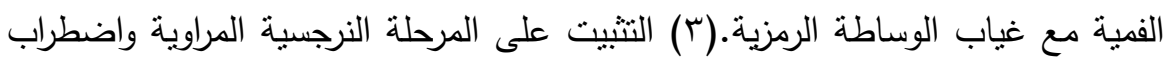

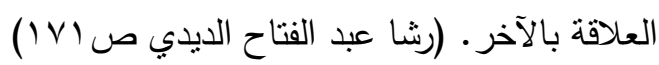

\section{قراسايت سائب}

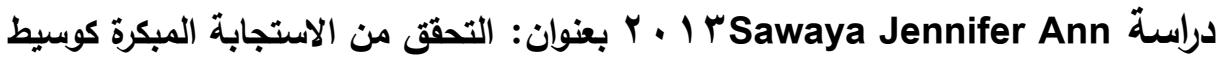
في مجموعة العلاج النفسي بالنسبة للنساء اللتين يعانون من اضطراب ما بعد الصدمة

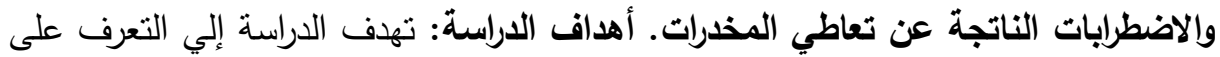

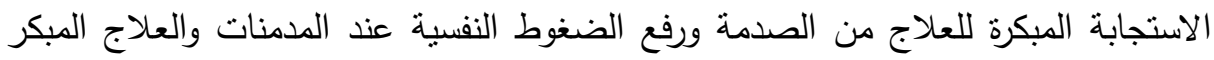
وتحسن الأعراض خلال الأسابيع الأولى من ؟ ؛ 1 أسابيع ويحدث تحسن على المدي البعيد أهتم الدارس بالتحالف العلاجى. أدوات الدراسة:البيانات من التجارب الدسبقة للعلاج في العلاج المبكر للصدمة واستخدت منحنيات القيم منحني التحول خيار نموذج الوساطة

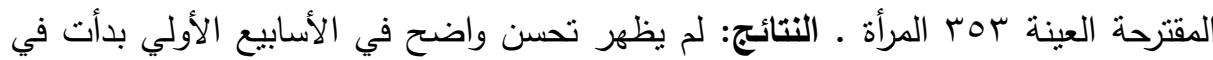

$$
\text { المجلد السايع والثلاثون، الجزء الثالث، مارس VI ا ب r }
$$


الأسبوع الرابع ويدعم صحة التتبؤية للعلاج المبكر ويثير إلي أن أعراض الصدمة، وأوضح

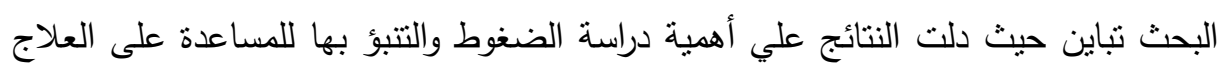
- المبكر

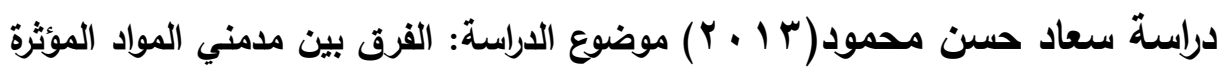
في الأعصاب ومرضى التثخيص المزدوج فيما يتعلق بالعوامل المؤدية للإنتكاسة.

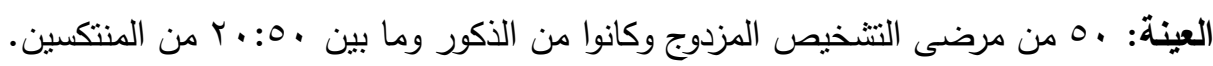

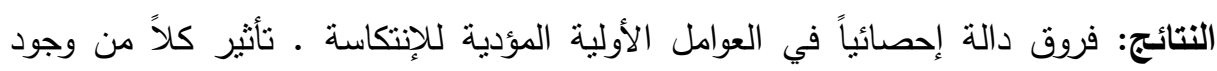

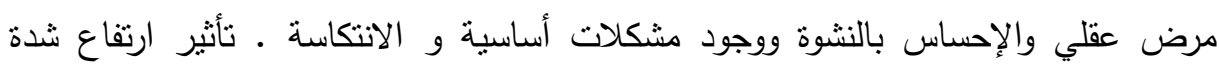

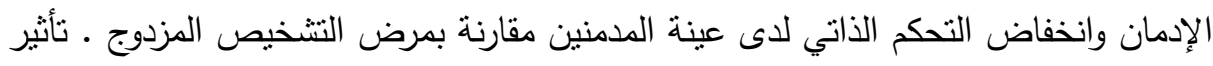

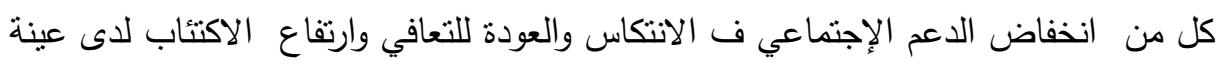

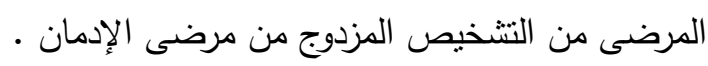

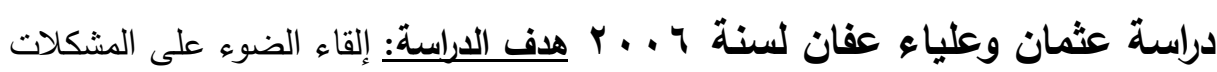
الاجتماعية الناتجة عن ظاهرة إدمان المخدارت واقتراح العلاج من منظور خدمة الفرد . استخدم المنهج الوصفي التحليلي، واعتمدت الدراسة على استمارة البيانات الأولية، ومقياس

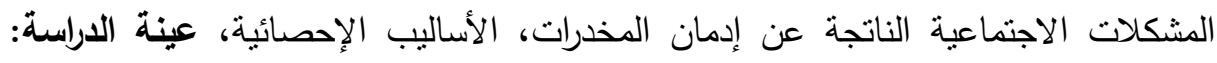

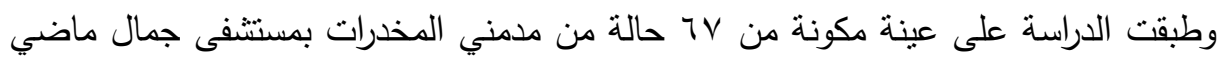

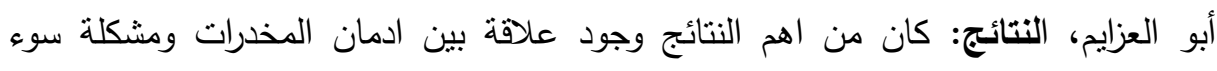

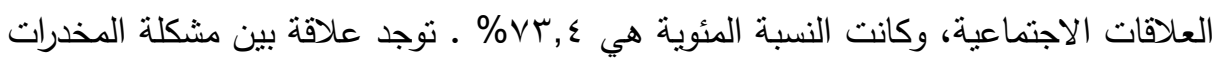

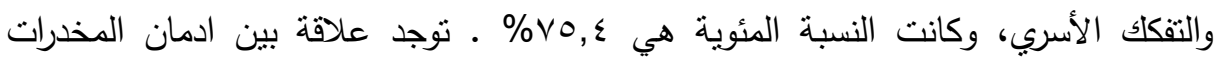

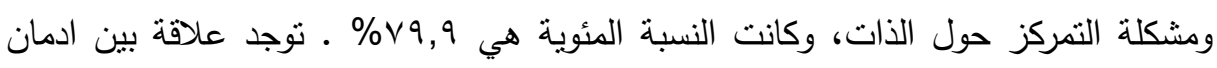

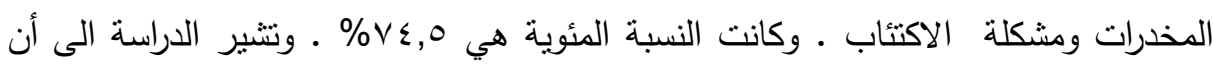

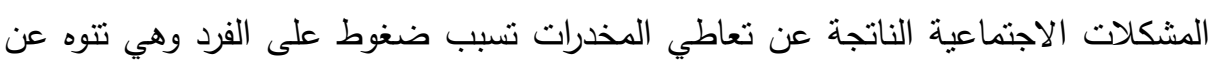

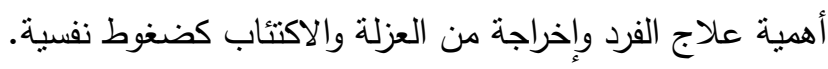


دراسة حسين علي خليفة(· ( · ) موضوعها: فعالية برنامج إرشادي لعلاج بعض الاضطرابات النفسية لاى متعاطي المخدرات من الطلاب الجماهيرية الليبية. هدف الاراسة: تهدف الدراسة الي علاج بعض الاضطرابات النفسية لدى متعاطي المخدرات

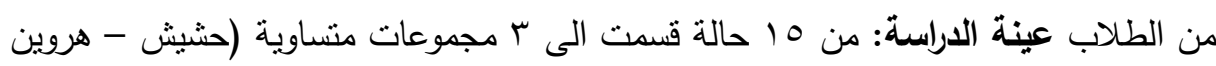

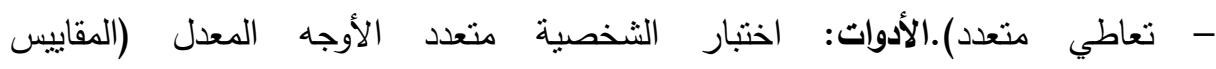

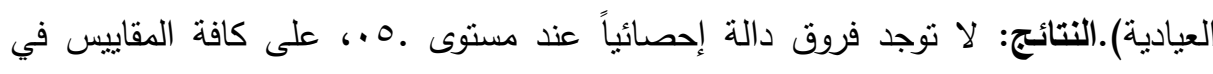

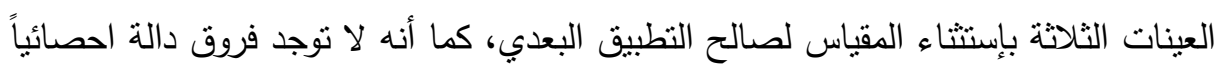
للعينات الثناثة بين التطبيق البعدي والتتبعي كما استخدم اختبار تقهم الموضوع والمقابلة الإكلينيكية لدراسة الحالة لمعرفة البناء النفسي لنخصية المتعاطي قبل البرنامج وبعده، حيث اظهرت النتائج أن هناك تحسن في البناء النفسي في التطبيق البعدي.

\section{xym}

تكونت العينة من • T سيدة، وقسمت الى · ب سيدة سبق لهن التعاطي، مدة لا تقل عن

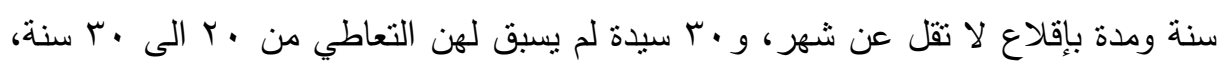

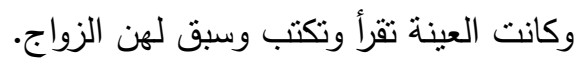

\section{أسوايت التوراسة}

أولاً: مقياس الضغوط النفسية للمرأة متعاطية المخدرات من تصميم الباحثة ثانياً: مقياس الضغوط البيئية للمرأة متعاطية المخدرات من تصميم الباحثة

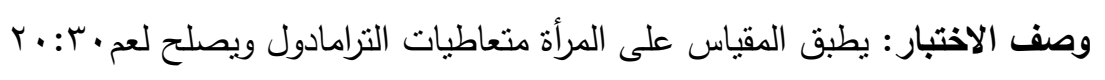

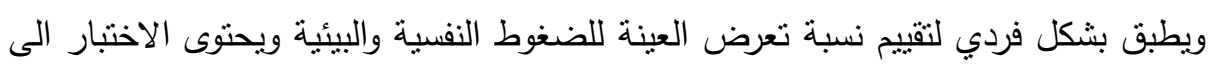
خمس محاور تتكون مع بعضها لتكون المقياس. 
تم تفريغ البيانات عن طريق البرنامج الإحصائي المعروف برنامج الحزم الإحصائية

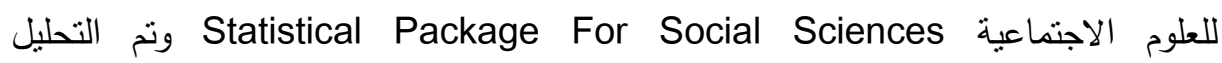

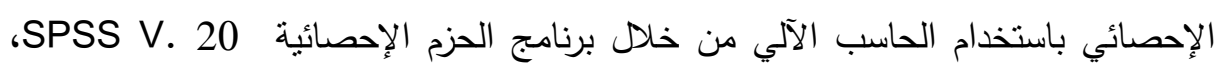

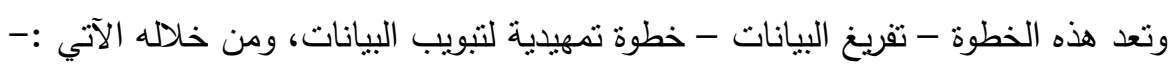

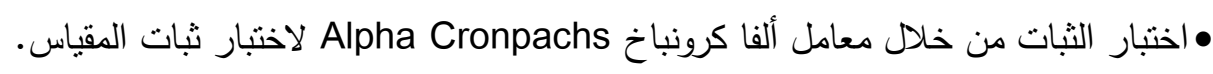
•اختبار صدق الإتساق الداخلي من خلال معامل ارتباط بيرسون بين الأبعاد وإجمالي لإني

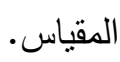
•اختبار "ت" T-Test لتوضيح الفروق بين عينة الدراسة تبعاً لمتغير الددرسة والنوع. • إيجاد العلاقات الارتباطية بمعامل ارتباط بيرسون لأبعاد الدراسة.

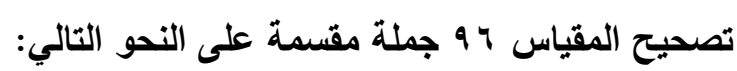

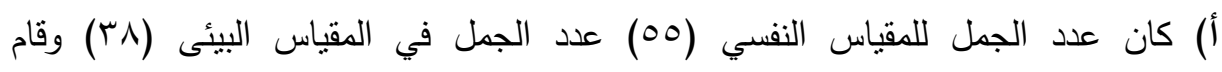

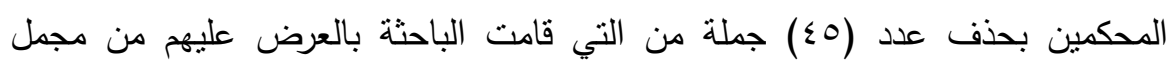

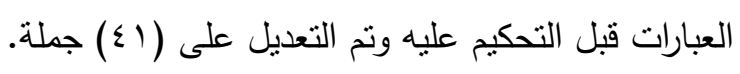

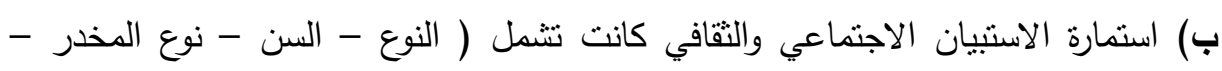

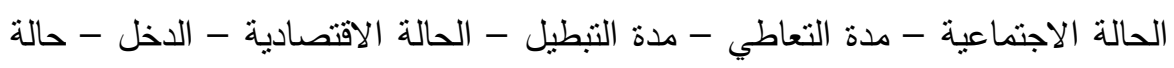

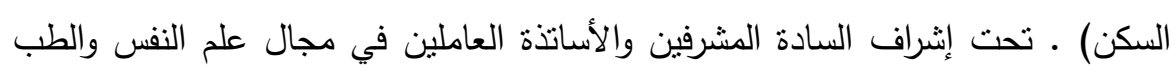

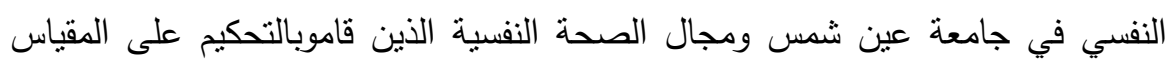
والإثراف عليه حتى ظهرت نتائجه. يعتمد المقياس على التنرج الثلاثى في النقدير الوزنى في العبارات إلى ( دائما- احسانا-

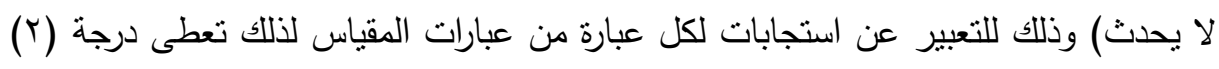

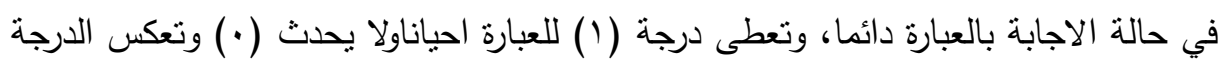

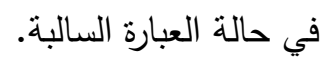

صدق الإتساق الااخلي للمقياس: تم حساب معاملات ارتباط كل بعد من أبعاد المقياس

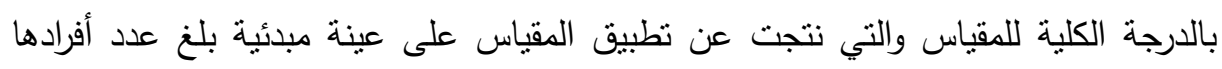

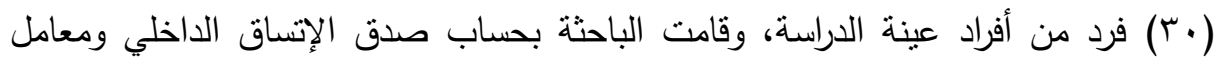

$$
\text { المجلد السايع والثلاثون، الجزء الثالث، مارس Y Y r T }
$$


الارتباط المصحح ويوضح جدول (r) أن صدق الاتساق الداخلي لعبارات الضغوط النفسية

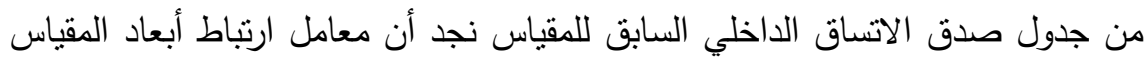

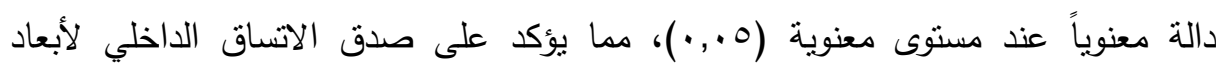

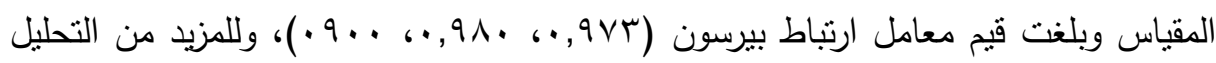

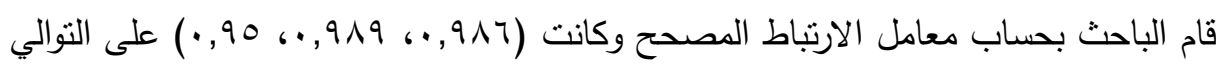
وهي قيم تؤكد على صدق المقياس.

Cronbach) ثبات المقياس: للتحقق من ثبات المقياس استخدم الباحث معادلة ألفا كرونباخ Alpha)، ويوضح الجدول التالي معاملات الثبات الناتجة باستخدام هذه المعادلة ويوضح

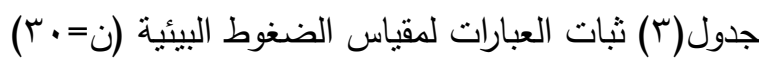

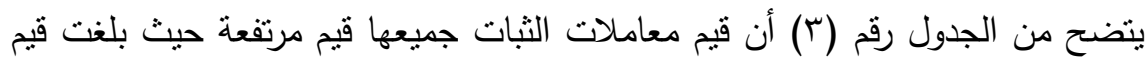

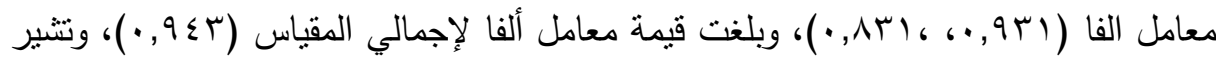

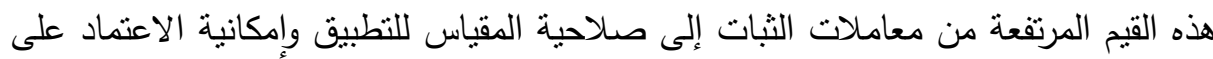
نتائجه والوثوق به. صدق الإتساق الاخاخي للمقياس: تم حساب معاملات ارتباط كل بعد من أبعاد المقياس بالدرجة الكلية للمقياس والتي نتجت عن تطبيق المقياس على عينة مبدئية بلغ عدد أفرادها

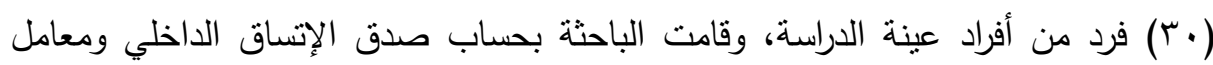
الارتباط المصحح ويوضح جدول (0) صدق الاتساق الداخلي لعبارات الضغوط النفسية

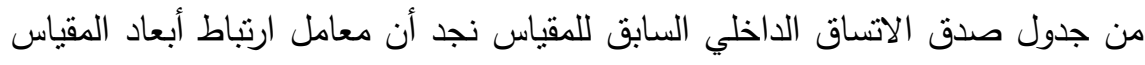

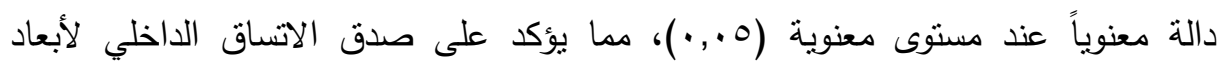

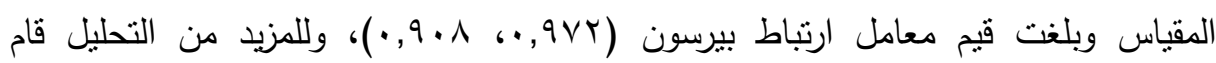
الباحث بحساب معامل الارتباط المصحح وكانت (99, •، 90, • •)على التوالي وهي قيم تؤكد على صدق المقياس. 
الثبات والصدق: ثبات المقياس: للتحقق من ثبات المقياس استخدمت الباحثة معادلة ألفا كرونباخ (Alpha Cronbach)، ويوضح الجدول التالي معاملات الثبات الناتجة باستخدام هذه المعادلة:

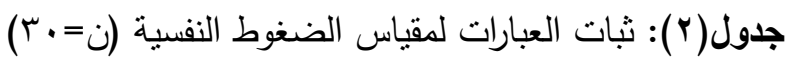

\begin{tabular}{|c|c|c|}
\hline قيمة آلفا & عدد العبارات & آبعاد المقياس \\
\hline$\cdot, 90 \pi$ & 11 & الضغوط الجسمانية \\
\hline$\cdot, 9 \leqslant V$ & Tr & الضغوط النفسية \\
\hline$\cdot$, AVY & $1 \varepsilon$ & الضغوط الاقتصادية \\
\hline$\cdot, 9 \vee 7$ & 00 & إجمالى مقياس الضغوط النفسية \\
\hline
\end{tabular}

يتضح من الجدول السابق أن قيم معاملات الثبات جميعها قيم مرتفعة حيث بلغت قيم

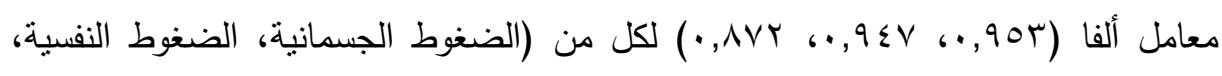

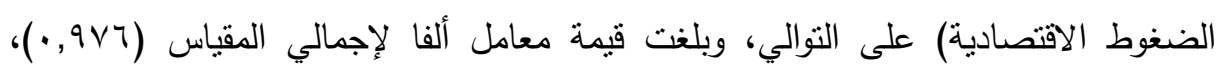
وتثير هذه القيم المرتفعة من معاملات الثبات إلى صلاحية المقياس للتطبيق وإمكانية

$$
\text { الاعتماد على نتائجه والوثوق به. }
$$

صدق الإتساق الداخلي للمقياس: نم حساب معاملات ارتباط كل بعد من أبعاد المقياس بالدرجة الكلية للمقياس والتي نتجت عن تطبيق المقياس على عينة مبدئية بلغ عدد أفرادها

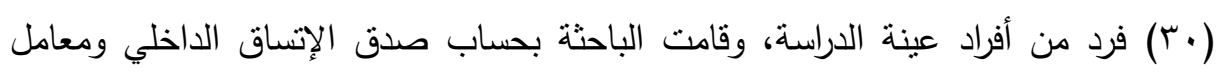

$$
\text { الارتباط المصحح كالآتي: }
$$

\begin{tabular}{|c|c|c|c|}
\hline معامل الارتباط المصحح & إجمالي المقياس & \multicolumn{2}{|c|}{ أبعاد المقياس } \\
\hline \multirow{2}{*}{$\cdot, 9 \wedge 7$} & $(* *) \cdot, 9 \vee \Gamma$ & معامل ارتباط بيرسون & الضغوط \\
\hline & $\cdot, \cdots 1$ & الدلالة المعنوية & الجسمانية \\
\hline \multirow{2}{*}{$\cdot, 919$} & $(* *) \cdot, 9 \wedge$. & معامل ارتباط بيرسون & \multirow{2}{*}{ الضغوط النفسية } \\
\hline & $\cdot, \cdots 1$ & الدلالة المعنوية & \\
\hline \multirow[t]{2}{*}{$\cdot, 9 \leq V$} & $(* *) \cdot, 9 \ldots$ & معامل ارتباط بيرسون & \multirow{2}{*}{ الاقتصنودية } \\
\hline & $\cdot, \cdots 1$ & الدلالة المعنوية & \\
\hline
\end{tabular}

جدول(ץ): صدق الاتساق الداخلي لعبارات الضغوط النفسية 
من جدول صدق الاتساق الداخلي السابق للمقياس نجد أن معامل ارتباط أبعاد المقياس دالة معنوياً عند مستوى معنوية (0.,.•)، مما يؤكد على صدق الاتساق الداخلي لأبعاد

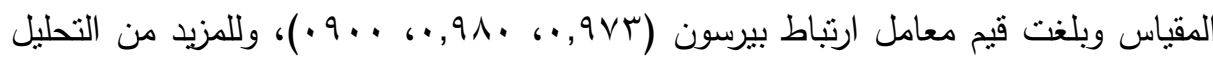

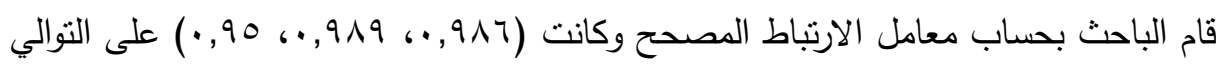
وهي قيم تؤكد على صدق المقياس. Cronbach) ثبات المقياس: للتحقق من ثبات المقياس استخدم الباحث معادلة ألفا كرونباخ Alpha )، ويوضح الجدول التالي معاملات الثبات الناتجة باستخدام هذه المعادلة:

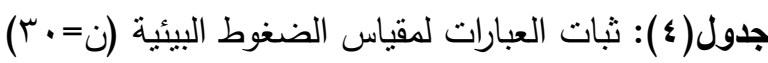

\begin{tabular}{|c|c|c|}
\hline قيمة آلفا & عدد العبارات & آبعاد المقياس \\
\hline (.,9ए। & Tr & الضغوط الاجتماعية \\
\hline • ( & 10 & الضغوط الفيزيقية \\
\hline$\cdot, 9 \leq \mu$ & ra & إجمالى مقياس الضغوط البيئية \\
\hline
\end{tabular}

يتضح من الجدول السابق أن قيم معاملات الثبات جميعها قيم مرتفعة حيث بلغت قيم

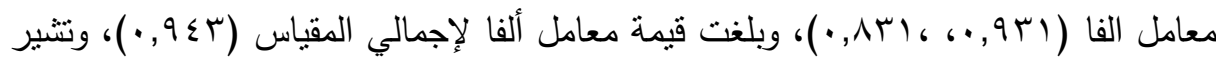

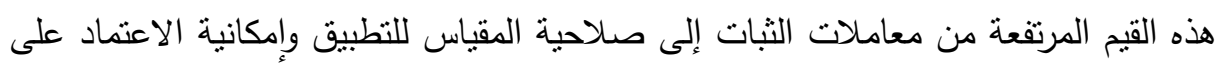

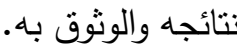
صدق الإتساق الداخلي للمقياس: تم حساب معاملات ارتباط كل بعد من أبعاد المقياس بالدرجة الكلية للمقياس والتي نتجت عن تطبيق المقياس على عينة مبدئية بلغ عدد أفرادها

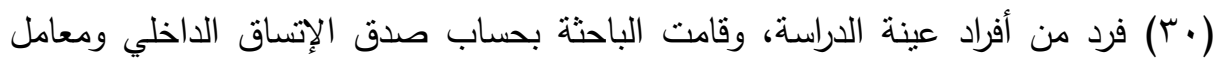

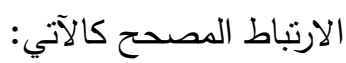
جدول(ه): صدق الاتساق الداخلي لعبارات الضغوط النفسية

\begin{tabular}{|c|c|c|c|}
\hline معامل الارتباط المصحح & إجمالي المقياس & \multicolumn{2}{|c|}{ أبعاد المقياس } \\
\hline \multirow{2}{*}{$\cdot, 99$} & $(* *) \cdot, 9 \vee Y$ & معامل ارتباط بيرسون & \multirow{2}{*}{ الضغوطماعبية البيئية } \\
\hline & $\cdot, \ldots 1$ & الدلالة المعنوية & \\
\hline \multirow{2}{*}{$\cdot, 90$} & $(* *) \cdot, 9 \cdot 1$ & معامل ارتباط بيرسون & \multirow[t]{2}{*}{ الضغوط الفيزيقية } \\
\hline & $\cdot, \cdots 1$ & الدلالة المعنوية & \\
\hline
\end{tabular}


من جدول صدق الاتساق الداخلي السابق للمقياس نجد أن معامل ارتباط أبعاد المقياس

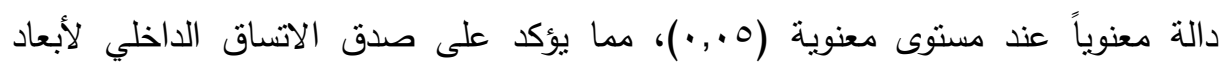

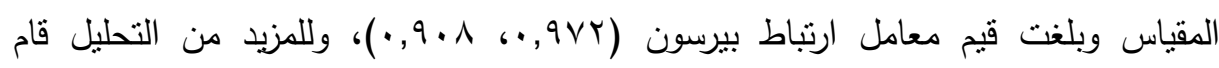
الباحث بحساب معامل الارتباط المصحح وكانت (99, •، 90, • •) على التوالي وهي قيم تؤكد على صدق المقياس. ثالثاً: استمارة استبيان عليها البيانات الأولية من العينة محل الدراسة. وقد أوضحت استمارة الاستبيان أنه:

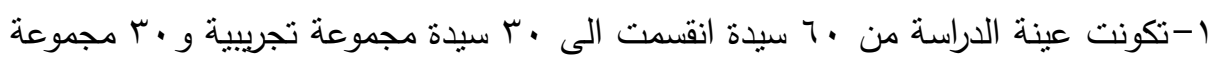

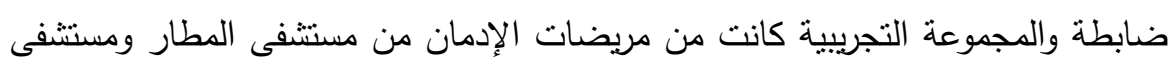
العباسية وقد سبق لهن الزواج وقد تعاطت الترامادول المدة لا تقل عن سنه ومده تبطيل لا لإنس تقل عن شهر والعينة جميعيها تقرا وتكتب والسن من ·r الى .r ب عاما وكانت العينة

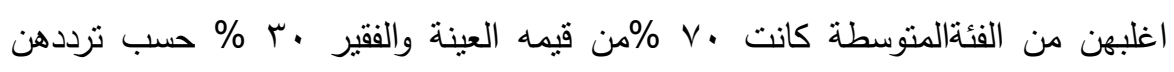

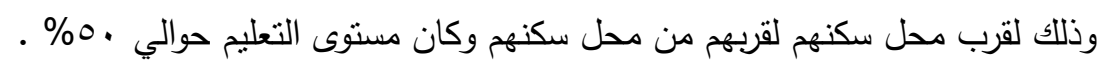

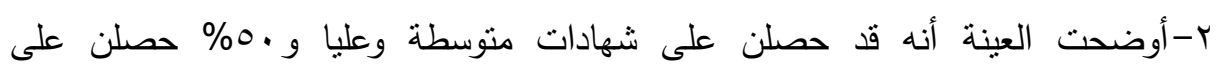

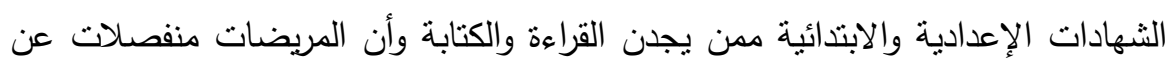

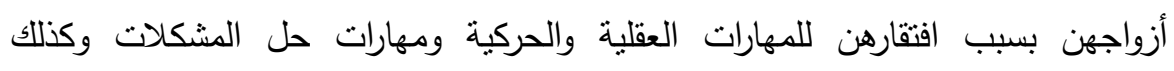

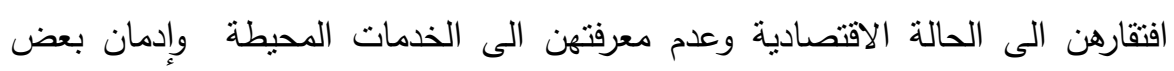

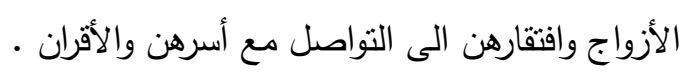

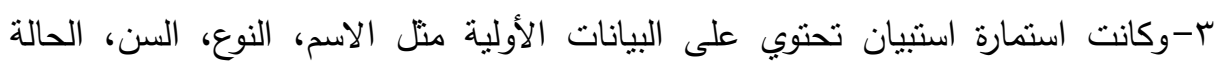

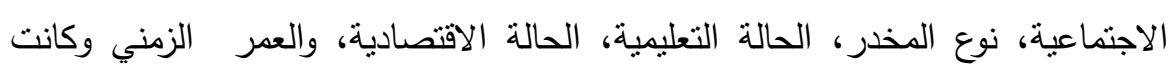

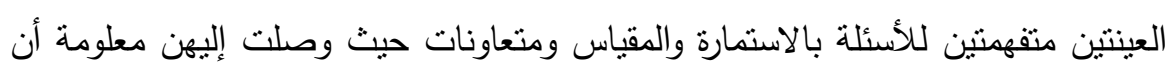

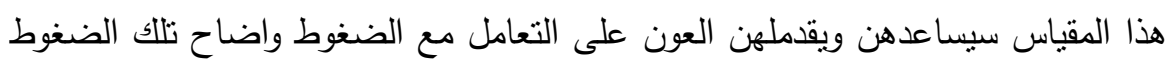

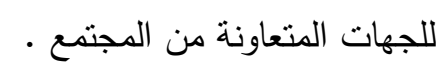

ع-أوضحت استمارة استنيان أن النسبة الأقل لتعاطى الترمادول من السيدات الاتي تعرضن لعمليات جراحية الام مزمنة أو من يعملن ساعات طويله وهن معيلات. 
ه-ان المرأة في سن العشرين والثناثثن يقع عليهن أعباء كثيرة وتوترات تصاحب اقترانهن بشريك الحياة.

צ-ان التزمادول في متتاول أيديهن وأنه حوالى .0 \% من العينة تتعاطهن وتساعد على تشتغيل مواد إدمانية اخرى.

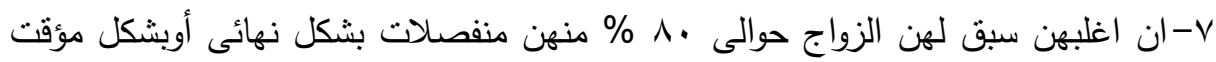
لعدم قدرتهن على التواصل واداء واجباتهن وارتفاع الاندفاع لايهن.

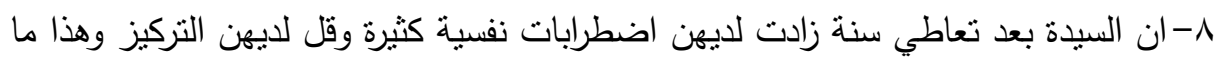
يتضح في نتيجة المقياس.

9-أن الحالة الاقتصادية لايهن متدهورة أوقد تدهورت الى حد كبير بسبب الادمان والعلاج

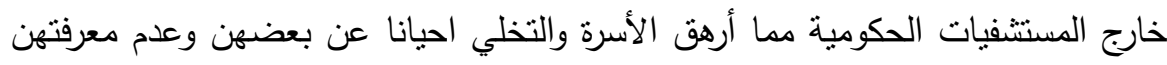
بالخدمات المحيطة بهن. • 1- أغلب الحالات أو •^ \% من الحالات لم يكن لديهن دخل خاص بهن والتي لديهن دخل خاص بهن لم يسطعن العمل لسوء حالتهن الصحية.

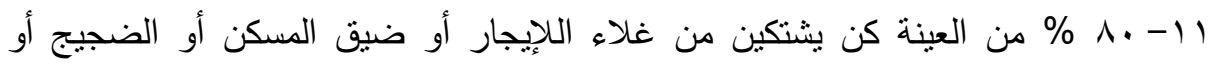
سكنتهن مع الأُسر الممتدة وكثرة التوترات والمشاكل أوقرب تجار المخدرات منهن وسهولة

رابعاً: الملاحظة المتعقة للمريضات من خلال عمل الباحثة: ومن الملاحظة المتعمقة للمريضات من خلال عمل الباحثة مع التسجيل لكل الملاحظات وتكرارها، وجد أنهن يفتقرن الى المهارات العقلية واليدوية والوازع الديني والاعتمادية والاندفاعية الزائدة وافتقار الإرادة أمام تبطيل المخدر ، وانهن يحتجن الى المساعدة من الفريق وكل من حولهن . خامساً: برنامج يطبق على المريضات بقسم السيدات التي تعمل به الباحثة: (برنامج رفع

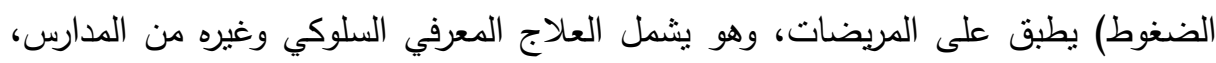
ويقوم الفريق على الجلسات الجماعية والفردية والأسرية، وتقوم الباحثة بعمل أنشطة فنية إنية وتتمل ( ورش عمل بانظام باستدعاء قصور الثقافة - رسم - فنون تشكيلية - أعمال إبرة -

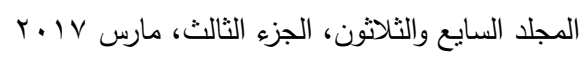


حياكة - عمل لوحات تعليمية - عمل جلسات تتمية بشرية - عمل جلسات قراءة - مناقثات حوارية - مسابقات - مناظرات - صحة إنجابية - حل مشكلات أسرية بالتواصل مع الأهل )

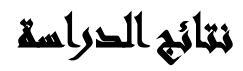

نتائج الفرض الأول: نتائج اختبار (ت) لحساب دلالة الفروق بين منوسطي المجموعة الضابطة والتجريبية لدرجات أفراد مجموعة الدراسة لمقياس الضغوط الأبار الجسمانية

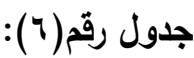

\begin{tabular}{|c|c|c|c|c|c|c|}
\hline \multirow{2}{*}{ مستوي } & \multirow{2}{*}{ قيمة (ت) } & \multicolumn{2}{|c|}{ 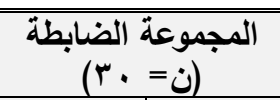 } & \multicolumn{2}{|c|}{ 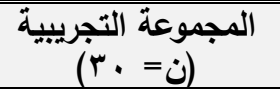 } & \multirow{2}{*}{ المتغيرات } \\
\hline & & الانحراف & المتوسط & الانحراف & المتوسط & \\
\hline 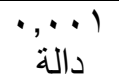 & $q, Y \backslash V$ & r,Y & $\uparrow, \wedge \uparrow$ & 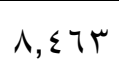 & $19,1 \pi$ & لـ الجسمانية \\
\hline
\end{tabular}

من الجدول السابق يتضح وجود فروق ذات دلالة إحصائية بين متوسطي درجات

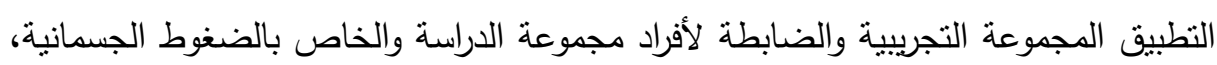

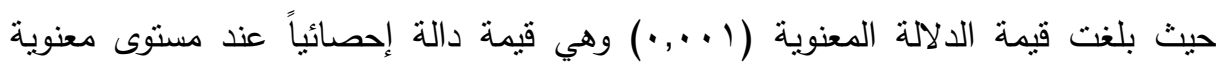

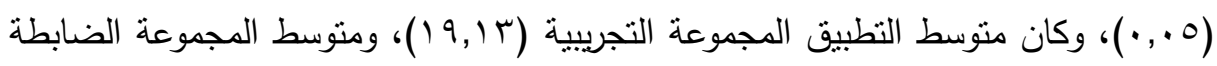

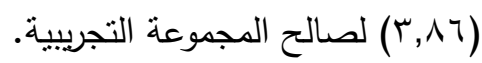

نتائج الفرض الثاني: نتائج اختبار (ت) لحساب دلالة الفروق بين منوسطي المجموعة الضابطة والتجريبية لدرجات أفراد

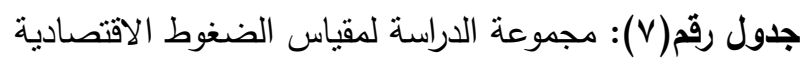

\begin{tabular}{|c|c|c|c|c|c|c|}
\hline \multirow{2}{*}{ الدلالةي } & \multirow{2}{*}{ قيمة (ت) } & \multicolumn{2}{|c|}{ 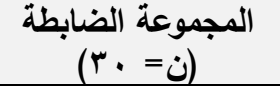 } & \multicolumn{2}{|c|}{ المجموعة التجريبية } & \multirow{2}{*}{ المتغيرات } \\
\hline & & الانحراف & المتوسط & الانحراف & المتوسط & \\
\hline ב' دالة, & $r$ & 0 , & $9,7 \pi$ & זrו, & $1 \varepsilon, \wedge$. & الاقتصنادية \\
\hline
\end{tabular}


من الجدول السابق يتضح وجود فروق ذات دلالة إحصائية بين متوسطي درجات المجموعة التجريبية والمجموعة الضابطة والخاص بالضغوط الاقتصادية، حيث بلغت قيمة

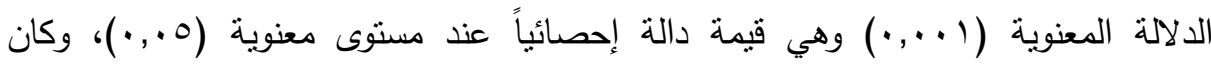

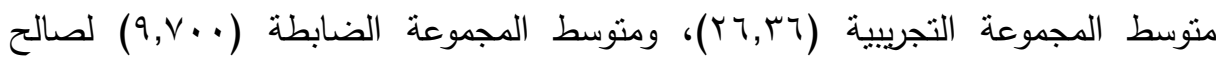
المجموعة التجريبية ـ لذلك تتبت صحة الفرض الذى ينص على:" توجد فروق ذات دلالة إحصائية بين متوسط درجات أفراد الدراسة في مقياس الضغوط الاقتصادية للمجموعة الضابطة والتجريبية لصالح المجموعة التجريبية. نتائج الفرض الثالث: نتائج اختبار (ت) لحساب دلالة الفروق بين منوسطي المجموعة الضابطة والتجريبية لدرجات أفراد مجموعة الدراسة لمقياس الضغوط النفسية

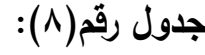

\begin{tabular}{|c|c|c|c|c|c|c|}
\hline \multirow{2}{*}{ الدلالة } & \multirow{2}{*}{ قيمة (ت) } & \multicolumn{2}{|c|}{ 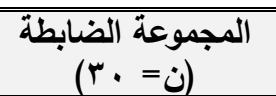 } & \multicolumn{2}{|c|}{ 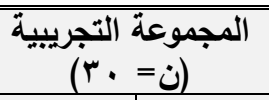 } & \multirow{2}{*}{ المتغيرات } \\
\hline & & الانحراف & المتوسط & الالمعياري & المتوسط & \\
\hline 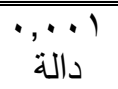 & $\vee, \wedge ৭ \wedge$ & $M, V Y$ & $r r, r$. & דr, & $\tau \cdot r$. & مقياس النفية \\
\hline
\end{tabular}

من الجدول السابق يتضح وجود فروق ذات دلالة إحصائية بين متوسطي درجات النطبيق للمجموعة التجريبية والمجموعة الضابطة والخاص بالضغوط النفسية حيث بلغت قيمة

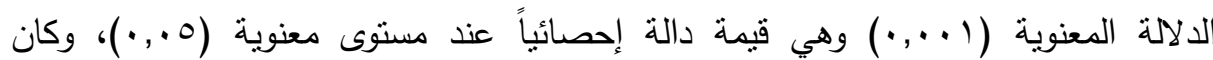

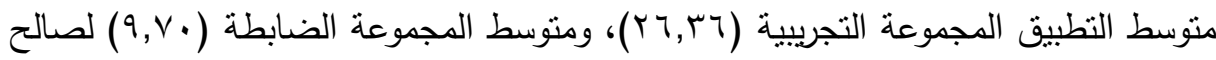

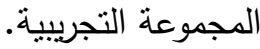


نتائج الفرض الرابع: نتائج اختبار (ت) لحساب دلالة الفروق بين منوسطي المجموعة الضابطة والتجريبية لدرجات أفراد مجموعة الدراسة لمقياس الضغوط الترار الاجنماعية.

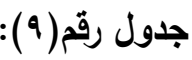

\begin{tabular}{|c|c|c|c|c|c|c|}
\hline \multirow{2}{*}{ الدالةوي } & \multirow{2}{*}{ قتيمة } & \multicolumn{2}{|c|}{ 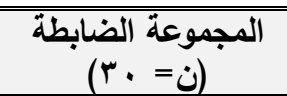 } & \multicolumn{2}{|c|}{ 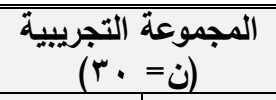 } & \multirow{2}{*}{ المتغيرات } \\
\hline & & الانحراف & المتوسط & الانحراف & المتوسط & \\
\hline 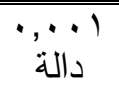 & $\varepsilon, 9 Y \wedge$ & דצ'T, & 17,1 . & $1 \cdot, \times 19$ & $r V, r$. & ط الاجتماعية \\
\hline
\end{tabular}

من الجدول السابق يتضح وجود فروق ذات دلالة إحصائية بين متوسطي درجات

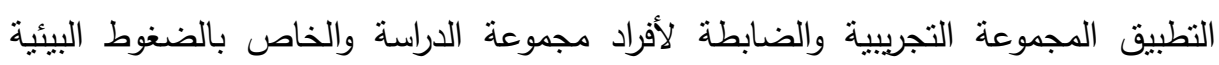

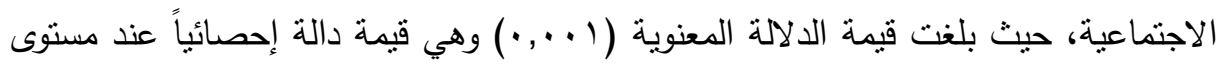

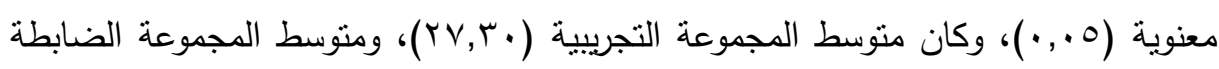

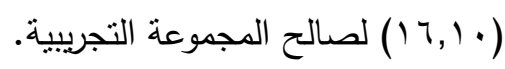

نتائج الفرض الخامس: نتائج اختبار (ت) لحساب دلالة الفروق بين متوسطي المجموعة الضابطة والتجريبية لدرجات أفراد مجموعة الدراسة لمقياس الضغوط الفيزيقية

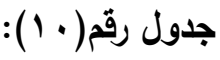

\begin{tabular}{|c|c|c|c|c|c|c|}
\hline \multirow{2}{*}{ مستولة } & \multirow{2}{*}{ قَت } & \multicolumn{2}{|c|}{ 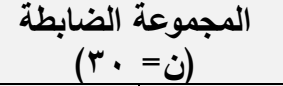 } & \multicolumn{2}{|c|}{ المجوعة التجريبية } & \multirow{2}{*}{ المتغيرات } \\
\hline & & الانحراف & المتوسط & الانحراف & المتوسط & \\
\hline غير د," & - $7 \vee 9$ & $\varepsilon$, & r & דוצד & Tr,17 & الضيزيفية \\
\hline
\end{tabular}

من الجدول السابق يتضح عدم وجود فروق ذات دلالة إحصائية بين متوسطي درجات

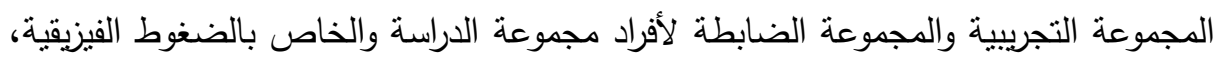

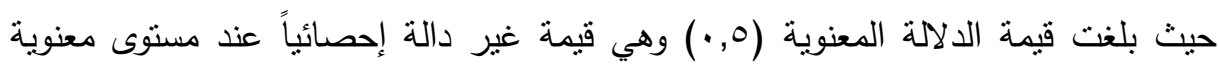

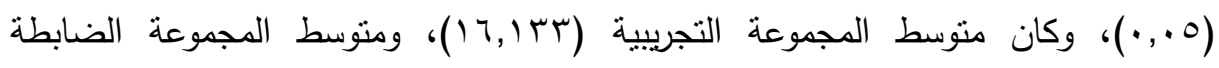


نتائج الفرض السادس: نتائج اختبار (ت) لحساب دلالة الفروق بين متوسطي المجموعة الضابطة والتجريبية لدرجات أفراد مجموعة الدراسة لمقياس الاتجاهات الاقتصادية

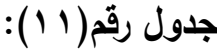

\begin{tabular}{|c|c|c|c|c|c|c|}
\hline \multirow{2}{*}{ مستوي } & \multirow{2}{*}{ قيمة (ت) } & \multicolumn{2}{|c|}{ 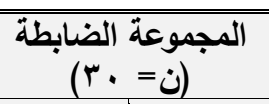 } & \multicolumn{2}{|c|}{ 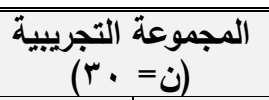 } & \multirow{2}{*}{ المتغيرات } \\
\hline & & الانعراف & المتوسط & الانعراف & المتوسط & \\
\hline دالة, & $\Gamma, 00$. & $q, \wedge \wedge \varepsilon$ & سז,ו & $17, \cdot r$ & $\varepsilon r, \varepsilon r$ & ـــ البيئية \\
\hline
\end{tabular}

من الجدول السابق يتضح وجود فروق ذات دلالة إحصائية بين منوسطي درجات

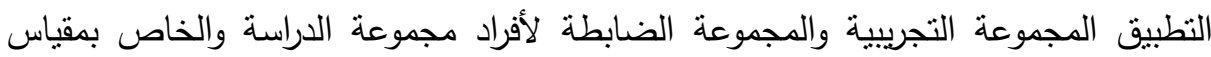
الضغوط البيئية

\section{تهمسير المنتائم}

أولأً: نتائج الفرض الاول: توجد فروق ذات دلالة إحصائية بين منوسط درجات افراد الدراسة في مقياس الضغوط النفسية ويدلل على النتائج جدول (†) للمجموعة الضابطة والتجريبية لصالح المجموعة التجريبية وقد اتققت نتائج الدراسة الحالية مع دراسة

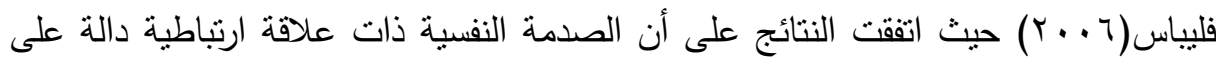
وجود علاقة بين تعاطي المخدرات والضغوط النفسية، ودراسة : ميلفورد جابى (V. . F )، اكتشاف الروابط بين الصدمة، اضطراب ما بعد الصدمة ومشاكل تعاطى المخدرات، كما

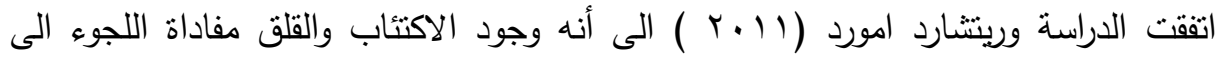

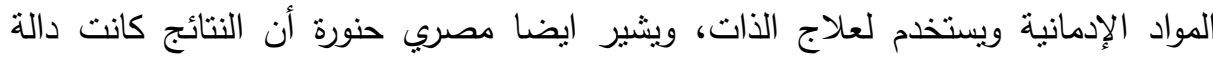
إحصائيا في تحديد المقارنة بين المدمنين المصريين والكويتين في وجود إضرابات نفسية

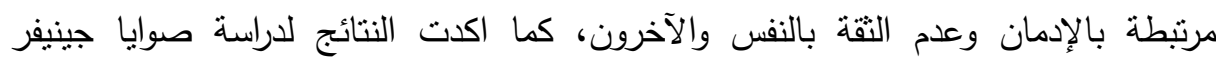

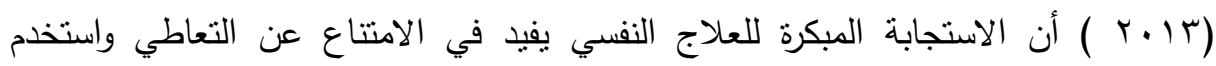

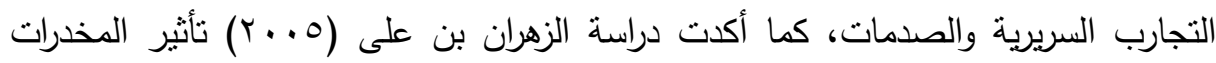

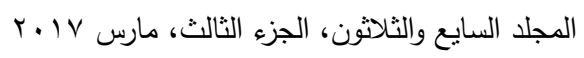


على الفرد المدمن وعلى السلوك الصادر منه أي أنه يتعرض للضغوط النفسية والجسمانية وقد تعود بالسلب على التعاطي.

- من الجدول رقم V يتضح وجود فروق ذات دلالة إحصائية بين متوسطي درجات التطبيق

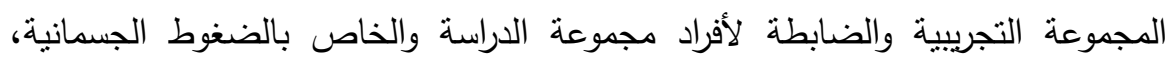

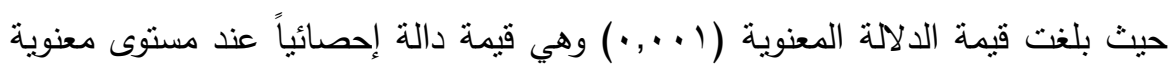

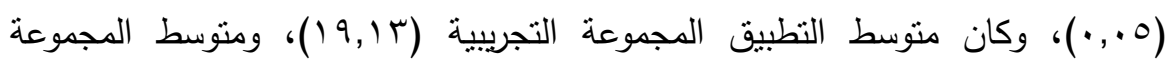
الضابطة (†,人, آ) لصالح المجموعة التجريبية.

لذلك تثبت صحة الفرض الذى ينص على:" توجد فروق ذات دلالة إحصائية بين منوسط

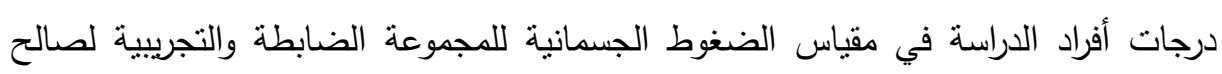
المجموعة التجريبية". ثانياً: عرض نتائج الفرض الثانى: اتفقت نتائج الدراسة الحالية مع رسالة الزهران بن

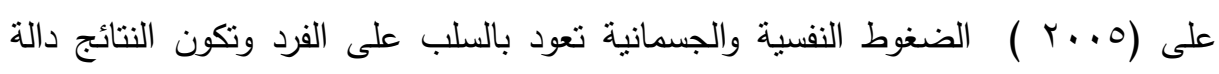

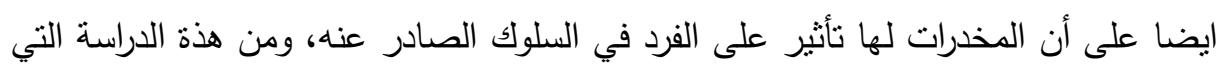

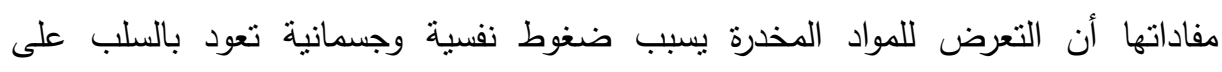

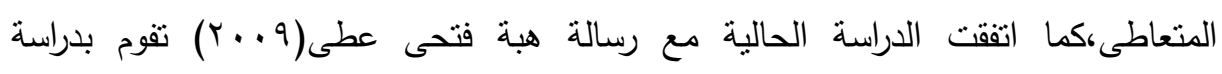

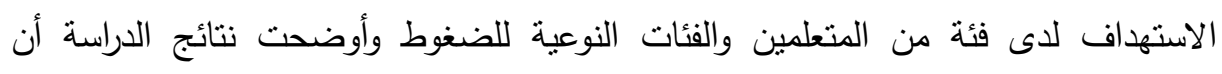

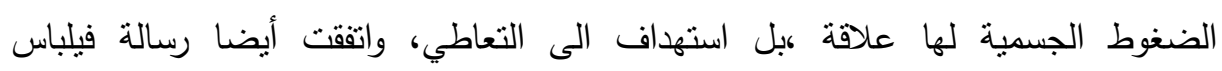

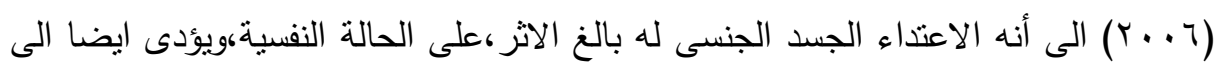

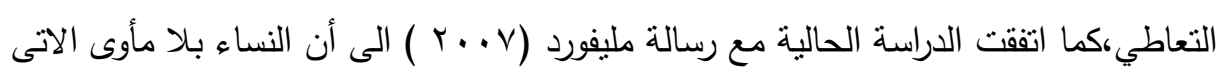

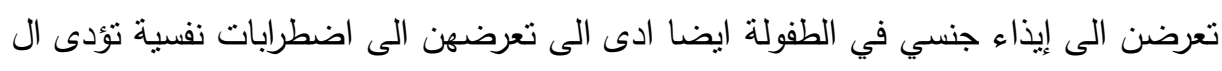

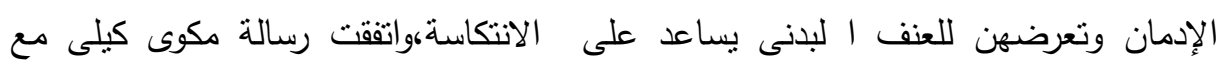

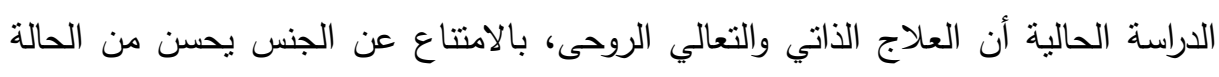

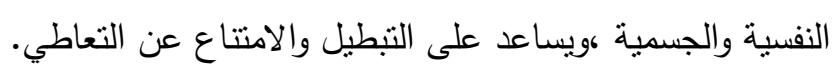
- من الجدول رقم (^) يتضح وجود فروق ذات دلالة إحصائية بين متوسطي درجات

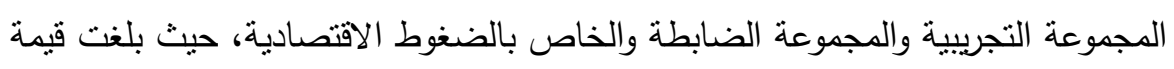

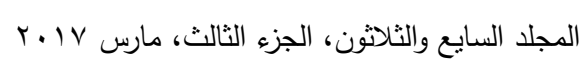


الدلالة المعنوية (1 . ., ) وهي قيمة دالة إحصائياً عند مستوى معنوية (0., •)، وكان

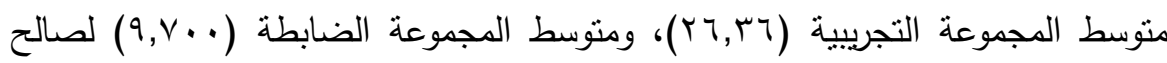
المجموعة التجريبية.

لذلك تثبت صحة الفرض الذى ينص على:" توجد فروق ذات دلالة إحصائية بين منوسط الفيد درجات أفراد الدراسة في مقياس الضغوط الاقتصادية للمجموعة الضابطة والتجريبية لصالح المجموعة التجريبية".

ثالثاً: عرض نتائج الفرض الثالث: أن هناك فروق ذات دلالة إحصائية بين الضغوط

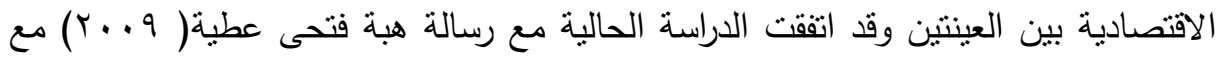
متغيرات الدراسة جميعها على عينة من الريفيين في قرية مصرية وعلاقة هذه الضغوط

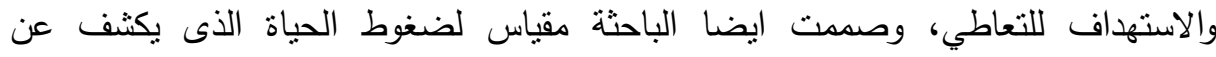
الضغوط -النفسية -الاقتصادية الاجتماعية -الجسمية - الرهنية - البيئية أوردت النتائج أن الضغوط وعلى رأسها الضغوط الاقتصادية نؤدى الى التعاطي وكذللك باقى الضغوط.

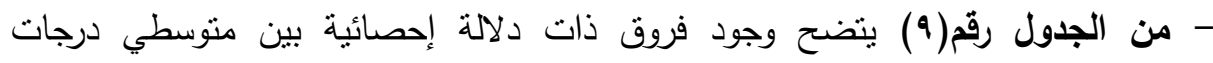

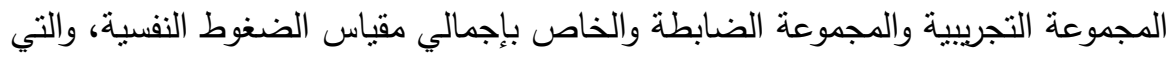
تم بناء المقياس في ضوئها، حيث بلغت قيمة الدلالة المعنوية (1 (., ,·) وهي قيمة دالة إحصائياً عند مستوى معنوية (0.,•)، وكان متوسط المجموعة التجريبية (•r, •؟))،

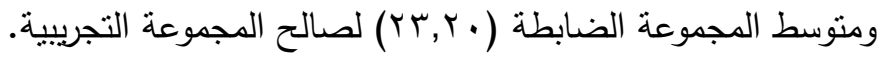
لذللك تثبت صحة الفرض الذى ينص على:" توجد فروق ذات دلالة إحصائية بين منوسط

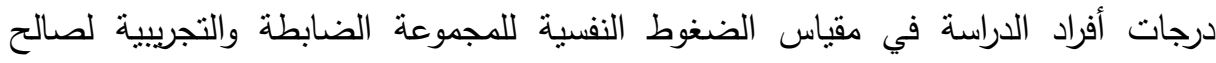

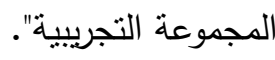
رابعاً: عرض نتائج الفرض الرابع: توجد فروض ذات دلالة إحصائية بين منوسط افراد الدراسة في مقياس الضغوط النفسية وجائت النتائج لصالح العينة التجريبية،واتفقت الدراسة

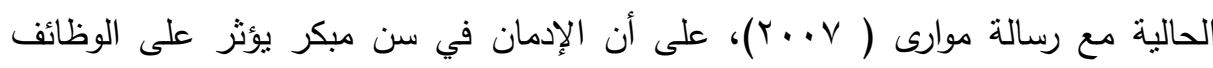

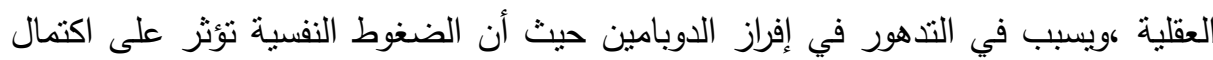

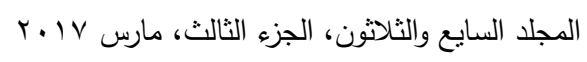


المخ وعدم تأدية الوظائف في التحكم ويؤدى الى انخفاض المقاومة للمادة الإدمانية،واتفقت

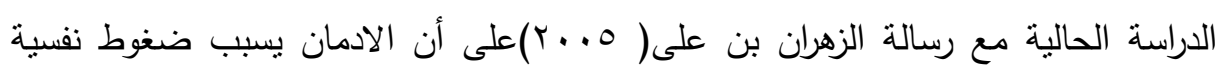

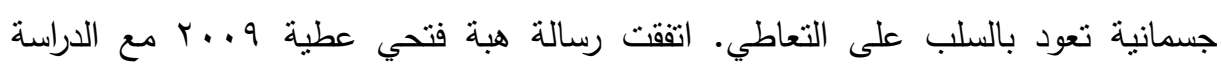

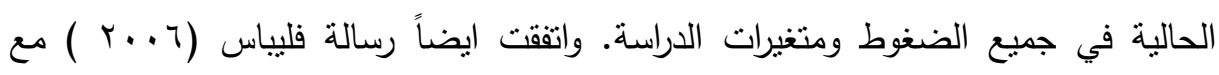
الدراسة الحالية أن الضغوط الجسمية والضغوط النفسية لها بالغ الاثر على التعاطي للمواد

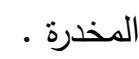
- اتفقت الدراسة الالية مع رسالة ريتشارد ( (1 + (ب).على وجود علاقة بين القلق والاكتئاب

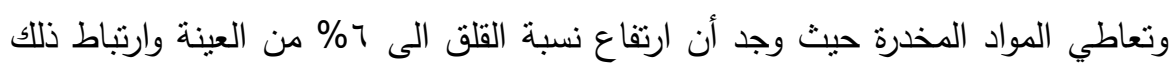
بالتعاطي للمواد الإدمانية كنوع من علاج الذات.

- ويتفق حنورة مع الدراسة الحالية فبمقارنة بين عينتيى الدراسة المصرية الدية والكوبينية في الضغوط النفسية والاكتآب وعدم الثقة بالنفس والاخرين كما اكد أن التغيرات الجنسية في في لئنة مرحلة المراهقة التي يكون مفاداها الجوء الى الادمان.

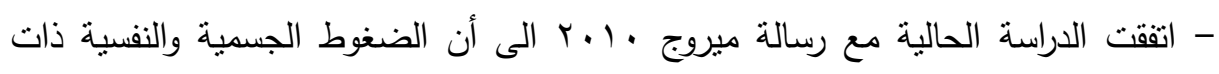
دلالة إحصائية وتؤدي ايضاً الى تعاطي المواد المخدرة.

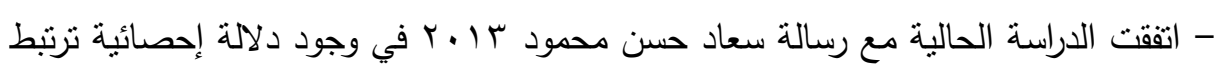
الضغوط النفسية وتعاطي المواد الإدمانية وأساسية الانتكاسة.

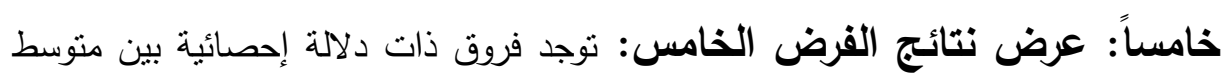
درجات أفراد الدراسة في مقياس الضغوط البيئية للمجموعة الضابطة والتجريبية لصالح المجموعة التجريبية جمن الجدول رقم ( • 1) ينضح وجود فروق ذات دلالة إحصائية بين

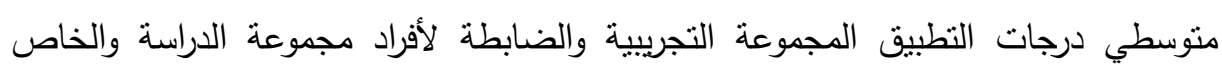

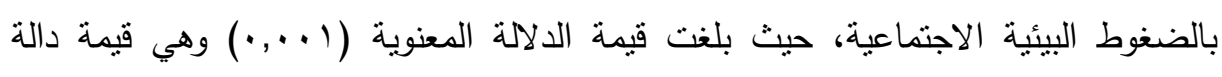

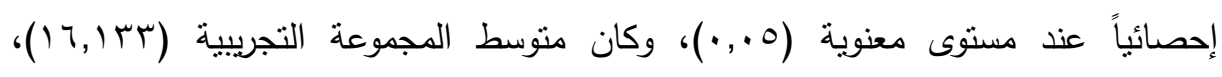

ومتوسط المجموعة الضابطة (بس إ, 17 (1) لصالح المجموعة التجريبية.

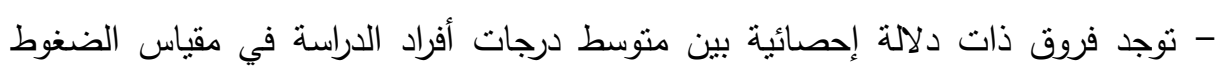
البيئية للمجموعة الضابطة والتجريبية لصالح التجريبية.

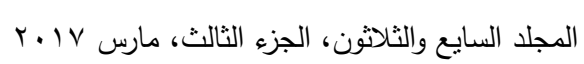


- اتفقت الدراسة الحالية مع رسالة بريفنشن، وقد أوردت النتائج أن أماكن الإقامة مثل أماكن

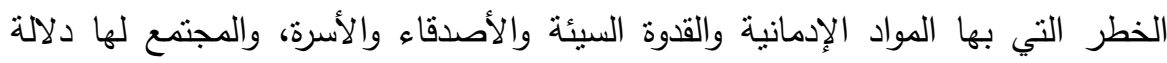
إحصائية على كثرة العوامل المؤدية على إدمان المراهقين.

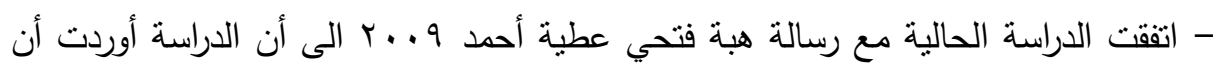

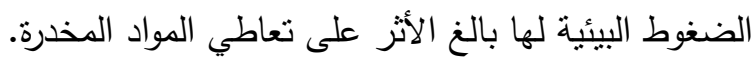

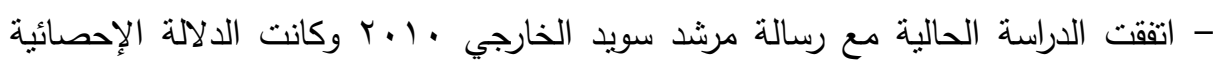
توضح أن الضغوط البيئية تؤثر على تعاطي المخدرات ولكن لا توجد فروق بينهم في التفاعل الاجنماعي أي اختلفت مع الدراسة الحالية في التفاعل الاجتماعي وعلاقتته بتعاطي المواد الإدمانية.

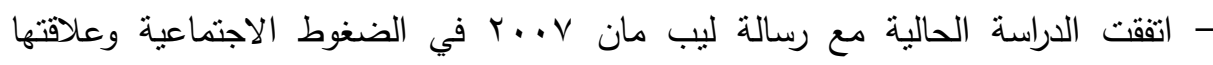
بالتخلف الدراسي ومشكلات إجتماعية من عدم تتبع الآباء لأبنائهم في سن صغيرة، وكانت

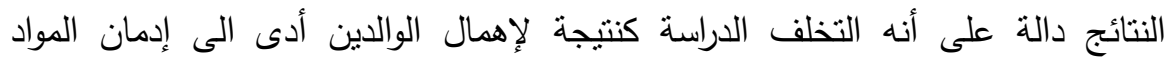
المخدرة.

- توجد فروق ذات دلالة إحصائية بين منوسط درجات أفراد الدراسة في مقياس الضغوط البيئية للمجموعة الضابطة والتجريبية لصالح التجريبية. - اتفقت الدراسة الحالية مع رسالة بريفنشن، وقد أوردت النتائج أن أماكن الإقامة مثل أماكن

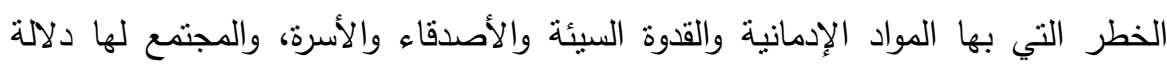
إحصائية على كثرة العوامل المؤدية على إدمان المراهقين.

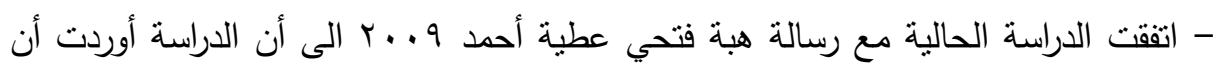
الضغوط البيئية لها بالغ الأثز على تعاطي المواد المخدرة. - اتفقت الدراسة الحالية مع رسالة مرشد سويد الخارجي • (. ب وكانت الدلالة الإحصائية

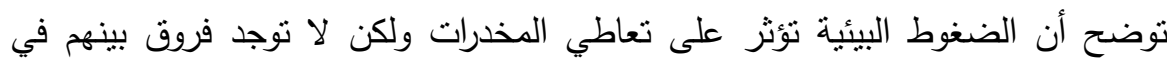

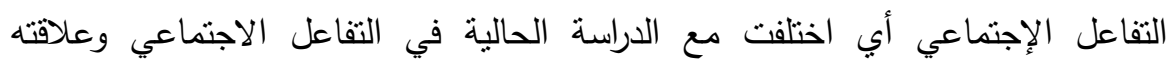
بتعاطي المواد الإدمانية. 
- اتفقت الدراسة الحالية مع رسالة ليب مان V. . . . في الضغوط الاجتماعية وعلاقتها بالتخلف الدراسي ومثكلات إجتماعية من عدم تتبع الآباء لأبنائهم في سن صغيرة، وكانت

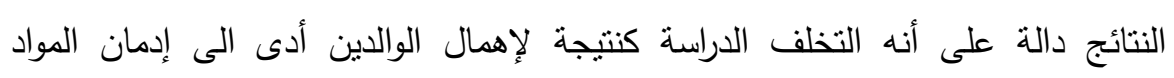

$$
\text { المخدرة. }
$$

- جدول (• (): نتائج اختبار (ت) لحساب دلالة الفروق بين منوسطي المجموعة الضابطة والتجريبية لدرجات أفراد مجموعة الدراسة لمقياس الضغوط الفيزيقية

- من الجدول رقم (• () يتضح عدم وجود فروق ذات دلالة إحصائية بين منوسطي درجات

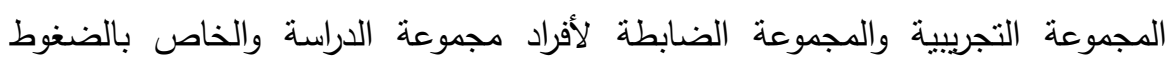

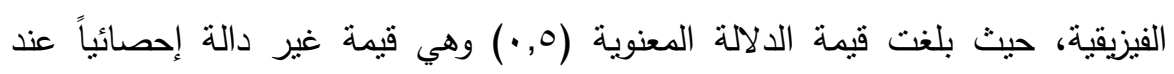

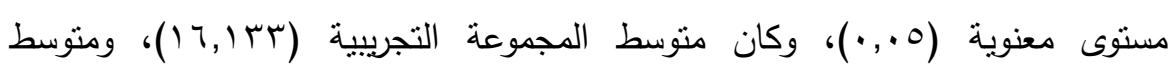

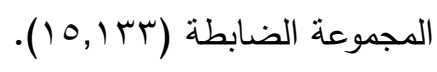

- جدول (1) (1) : نتائج اختبار (ت) لحساب دلالة الفروق بين متوسطي المجموعة الضابطة

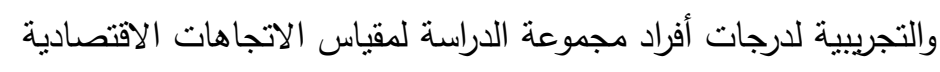

- يتضح وجود فروق ذات دلالة إحصائية بين متوسطي درجات النطبيق المجموعة التجريبية

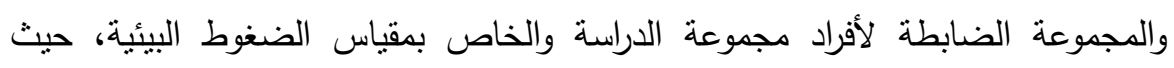

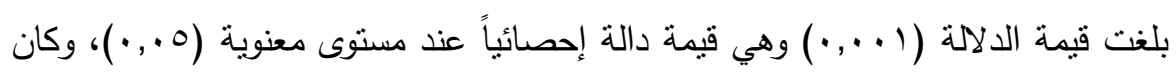

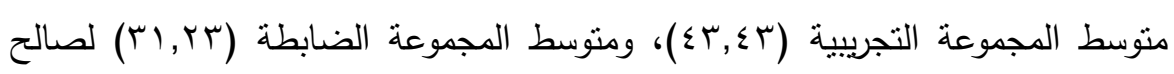

المجموعة التجريبية.

- لذلك تثبت صحة الفرض الذي ينص على:" أنه نوجد فروق ذات دلالة إحصائية بين متوسط درجات أفراد الدراسة في مقياس الضغوط النفسية للمجموعة الضابطة والتجريبية

$$
\text { لصالح المجموعة التجريبية". }
$$

نتائج الفرض السادس: توجد علاقة ذات دلالة إحصائية بين الضغوط النفسية والضغوط البيئية والجسمانية والاقتصادية في العينة التجريبية. - توجد علاقة ذات دلالة إحصائية بين الضغوط النفسية والضغوط البيئية والجسمانية والاقتصادية، وكانت النتائج لصالح العينة التجريبية. 
- اتفقت الدراسة الحالية مع رسالة هبة فتحي عطية 9 . . ب أنه توجد دلالة إحصائية بين كل متغيرات الدراسة وقد صممت الباحثة ايضاً مقياس لضغوط الحياة ويشمل الضغوط النفسية والبيئية وضغوط العمل، وكانت ذات دلالة إحصائية لصالح العينة التجريبية.

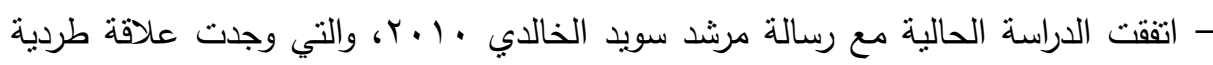
بين وجود الضغوط البيئية والمشكلات الأسرية والسلوك الإنحرافي لدى لدى المدمنين والمشكلات الأسرية والتفاعل الاجتماعي.

- وجود فروق دالة إحصائية بين منوسطي درجات أفراد عينة الدراسة في الضغوط البيئية (الاجتماعية والفيزيقية).

- وجود فروق دالة إحصائية بين متوسطي درجات أفراد عينة الدراسة في الضغوط النفسية والبيئية والجسمانية والاقتصادية في العينة التجريبية، لذلك ثبت صحة دردة الفرد الذي لله دلالة إحصائية.

ترى الباحثة: أن هذه النظرية هي الأقرب للاراسة الحالية وتتفق مع الدراسات السابقة أيضاً، وترى أيضاً أن التعامل مع ميكانيزمات التعامل مع الضغوط لنفي من خلال هذه النظرية بتفعيل

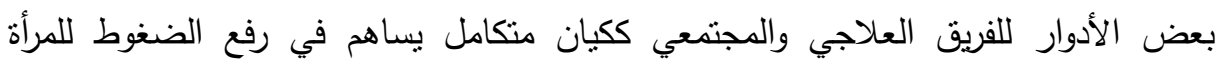
متعاطية المخدرات عينة البحث.

\section{اللتوسيايت}

1- دمج المرأة التي تخضع للعلاج في البرنامج العلاجي بتحفيز معنوي ومدي يساعدها علي البقاء في المصحة r- تعريف المرضيات الخدمات المحيطة في المجتمع r- تعريفهن بالمخاطر الأدمان والصحة الأنجابية ع- زيادة الرقعة الخضراء في البيئة ه- تشديد العقوبات علي الأفراد الذين يقومون بعمل ضجيج في المهنه

$$
\text { المجلد السايع والثلاثون، الجزء الثالث، مارس VI ا. r }
$$


1- أن تخضع المتعاطيات الي المسالة القانونية من خلال الجهة المختصة لذلك واختيرهن

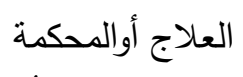

V- إخضاع كل الأُسر الي الفهم والمعرفة عن مخاطر الأدمان عن طريق الجهات المختصة لذلك

ᄉ- نوفير للنزيلات العلاج بالعمل وإعلاء مهارتهن العقلية واليدوية حيث أنهن يفتقرن لذلك

\section{المراليع}

رشا عبدالفتاح الديدي( ( . ب): المرأة والإدمان، دراسة نفسية واجتماعية من منظور التحليل

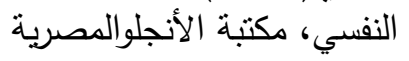

أكاديمية البحث العلمي(ع ( • r): القاهرة، شارع القصر العيني

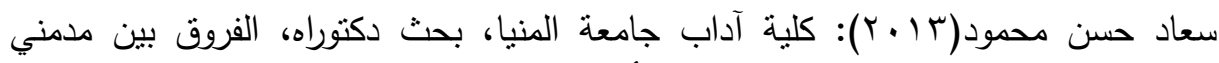

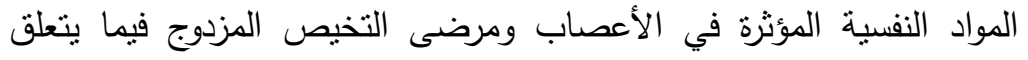

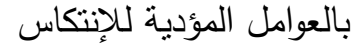

المركز القومي للبحوث الاجتماعية والجنائية ب ا ـr - الدورة ال بـ للمخدرات

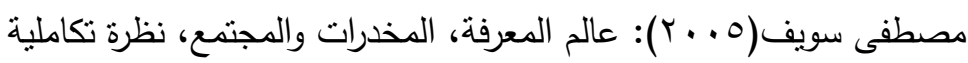
سهام محمد إبراهيم كامل(ب ( + ب): الاحتراق النفسي ( جامعة القاهرة، ماجستير في التربية )

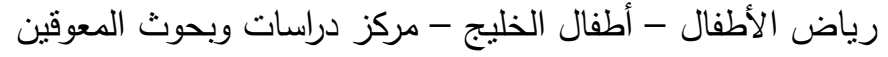

عثمان وعلياء عفان(T . . ץ): إلقاء الضوء على المشكلات الاجتماعية الناتجة عن ظاهرة

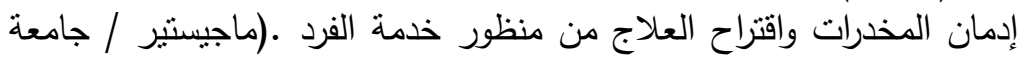

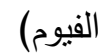
حسين علي خليفة الغول(· ( • ( ): فعالية برنامج إرشادي لعلاج بعض الاضطرابات النفسية لاى متعاطي المخدرات من الطلاب الجماهيرية الليبية النية

صندوق مكافحة وعلاج الإدمان رئاسة الوزراء - القاهرة - 10 . المركز القومي للبحوث الاجتماعية والجنائية با ــ (القاهرة) 


\title{
THE MECHANISMS OF DEALING WITH STRESS OF DRUG-ADDICTED WOMEN AN EXPERIMENTAL COMPARATIVE STUDY
}

Ahmed, G. Sh. ${ }^{(1)}$; Shoman, A. E. ${ }^{(2)}$; Hany, A. F. ${ }^{(3)}$ and ALsayed, Najwa, A. ${ }^{(4)}$

1) Institute of Postgraduate Child Hood Studies, Ain Shams University

2) Faculty of Medicine, Ain Shams University 3) Institute of Environmental Studies and Research, Ain Shams University

\begin{abstract}
Objective: This study purpose is to identify the stresses the addict woman suffers from in her way to recovery، then experiencing a setback' that is exposed by the Psychological and environmental scale designed by the researcher.

Study Sample: It consists of (60) items of females ، divided into (30) women as the control group and (30) women as the experimental group، aged from (20-30) year olds، previously married.

The Educational status: The control group items are to be reading and writing; while the experimental items are addicts to tramadol drug not for less than one whole year and take off not less than one month.

\section{Study Instruments:}

1- A Questionnaire form of the previously mentioned data and approval of the sample items.

2- Scale of Psychological Stress (by researcher).

3- Scale of environmental Stress (by researcher).

Results: Results indicate differences exist between healthy and ill women regarding their dealing with physical stress، followed by psychological، economic، social، and physical stress.
\end{abstract}

$$
\text { المجلد السايع والثلاثون، الجزء الثالث، مارس VI Y r }
$$

